University of Nebraska - Lincoln

DigitalCommons@University of Nebraska - Lincoln

Management Department Faculty Publications

Management Department

2008

Environmental Context, Managerial Cognition, and Strategic Action: An Integrated View

\author{
Sucheta Nadkarni \\ University of Nebraska - Lincoln, snadkarn@unlnotes.unl.edu \\ Pamela S. Barr \\ Georgia State University, Atlanta, Georgia, USA
}

Follow this and additional works at: https://digitalcommons.unl.edu/managementfacpub

Part of the Management Sciences and Quantitative Methods Commons

Nadkarni, Sucheta and Barr, Pamela S., "Environmental Context, Managerial Cognition, and Strategic Action: An Integrated View" (2008). Management Department Faculty Publications. 14.

https://digitalcommons.unl.edu/managementfacpub/14

This Article is brought to you for free and open access by the Management Department at DigitalCommons@University of Nebraska - Lincoln. It has been accepted for inclusion in Management Department Faculty Publications by an authorized administrator of DigitalCommons@University of Nebraska - Lincoln. 
Published in Strategic Management Journal 29 (2008), pp. 1395-1427; doi 10.1002/smj.717

Copyright (C) 2008 John Wiley \& Sons, Ltd. Used by permission. http://www.interscience.wiley.com

Submitted March 1, 2006; revised May 16, 2008; published online September 15, 2008.

\title{
Environmental Context, Managerial Cognition, and Strategic Action: An Integrated View
}

\author{
Sucheta Nadkarni ${ }^{1}$ and Pamela S. Barr ${ }^{2}$ \\ 1 Department of Management, University of Nebraska-Lincoln, Lincoln, Nebraska, USA \\ 2 Department of Managerial Sciences, Robinson College of Business, Georgia State University, Atlanta, Georgia, USA \\ Corresponding author - Sucheta Nadkarni, Department of Management, University of Nebraska-Lincoln, \\ Lincoln, NE 68588-0491, USA; email snadkarn@unlnotes.unl.edu
}

\begin{abstract}
This study addresses an apparent disconnect between two views of strategic action: the "economic view," which contends that industry structure is the primary influence on strategic action, and the "cognitive view," which suggests that managerial cognition drives strategic action. We argue that this disconnect has created artificial boundaries between the two perspectives and has limited our ability to develop holistic explanations of strategic action. In response, we develop an integrated model that answers two questions: 1) Does industry context affect managerial cognition? 2) Does managerial cognition mediate the relationship between industry context and strategic responses to environmental changes? To examine these questions, we study the relationship between industry velocity, the structure of top management's cognitive representation of the environment, and the speed of response to environmental events. We find that industry velocity influences the structure of cognitive representations, which in turn influence the speed of response to environmental events. These results support our contention that both industry and cognition variables are critical in developing explanations of strategic actions. These results have implications for our understanding of the development of top managers' beliefs, the relationship between beliefs and action, and the nature of the complex relationship between industry context, managerial cognition, and strategic action.
\end{abstract}

Keywords: attention, causal logic, cognition, environment, strategic action, velocity

\section{Introduction}

The question of what drives strategic action has occupied a central position in the strategic management literature. Although several explanations of strategic action have been developed, two views have been particularly dominant-industry structure and managerial cognition. The industry structure view assumes complete rationality on the part of strategic decision makers and contends that industry structure influences the timing and effectiveness of strategic actions (Bain, 1956; Caves, Fortunato, and Ghemawat, 1984; Ghemawat, 1991; Mason, 1957; Porter, 1985). In contrast, the managerial cognition literature suggests that bounded rationality prevents top managers from de- veloping a complete understanding of their environments (Bogner and Barr, 2000; Daft and Weick, 1984; Fiol and O'Connor, 2003). Instead, top managers develop subjective representations of the environment that, in turn, drive their strategic decisions and subsequent firm action. The two camps have progressed along independent lines; industry structure has focused on cross-industry differences in strategic actions, downplaying the role of cognition, whereas the managerial cognition view has focused on the role of cognition in determining strategic actions within a single industry, giving little attention to the nature of that industry. Because each camp focuses on distinct explanations of strategic actions, we believe that a disconnect between the two views has created artifi- 
cial boundaries between industry structure and managerial cognition as drivers of strategic action. These boundaries have, in turn, severely inhibited the development of comprehensive and integrated explanations of strategic action.

Recent studies have suggested that an integration of the industry structure and managerial cognition views may lead to a better and more complete explanation of strategic action (Johnson and Hoopes, 2003). For example, while cognitive boundedness prohibits the perfect rationality suggested by the industry structure view (Simon, 1991), the exogenous economic characteristics of industries do exist independently of managers' beliefs about them and "can force industry members to accept a reality that they might not have enacted on their own" (Johnson and Hoopes, 2003: 1,057). This suggests that a relationship between industry structure and managerial cognition may exist and may explain strategic action better than either perspective can on its own. Further, this connection brings to the foreground an assumption often implied, but not tested, in the cognition literature: that industry influences facets of managerial cognition, which affects how managers make sense of and act within their environments. If this is true, then it suggests that cognition mediates the relationship between industry context and strategic action. To investigate this possibility, this study addresses two questions:

- Does industry context affect managerial cognition about environments?

- Does managerial cognition mediate the relationship between industry context and strategic action?

We address these questions by focusing on top managers' subjective representations of their firms' operating environments. Both the strategic choice (Child, 1972) and upper echelon views (Hambrick and Mason, 1984) argue that top managers bring together and interpret information for the firm as a whole. Many may participate in scanning or data processing, but the point at which information converges and is interpreted for organizational-level action is presumed to be at the top manager level (Daft and Weick, 1984; Lyles and Schwenk, 1992; Prahalad and Bettis, 1986; Thomas, Clark, and Gioia, 1993). How top managers construct their environments has been argued to both influence which environmental events attract the attention of strategic decision makers and which events are selectively ig- nored in strategic decision making, as well as the nature of the response to environmental events (Bogner and Barr, 2000; Daft and Weick, 1984; Fiol and O'Connor, 2003). In other words, subjective representations that top managers develop about their environments help define the firm's strategic agenda (Dutton and Jackson, 1987).

We examine differences in two forms of subjective representations that top managers develop about environments - attention focus (the aspects of the environment that are central to top managers' subjective representations of their environments) and environment-strategy causal logics (the order of the perceived causal relationship between the external environment and firm strategy). Attention focus about the environment is important because it influences the degree of mindful attention that will be directed to a given environmental event (Weick, 1995) and influences the likelihood that any given environmental event will make it onto the firm's strategic agenda (Cho and Hambrick, 2006; Dutton and Jackson, 1987; Huff, 1990). Causal logics, on the other hand, are the primary basis for decision making in general (Fiske and Taylor, 1991) and have been found to influence the way in which strategic decisions are made, understood, and communicated (Huff, 1990).

We examine attention focus and causal logics of top managers in two different industry contexts: high velocity (semiconductor and cosmetic industries) and low velocity (aircraft and petrochemical industries). We propose that industry velocity will influence attention focus and causal logics that, in turn, will influence the speed of strategic action responses to major environmental changes. In other words, attention focus and causal logics will mediate the relationship between industry velocity and speed of strategic action responses to environmental changes. Our study provides unique insights on how the industry and cognitive views collectively explain strategic action.

\section{Theory Development and Hypotheses}

\section{Overview of theoretical model}

We present our theoretical model in Figure 1. The central contention of our model is that attention focus and causal logics that top managers develop 


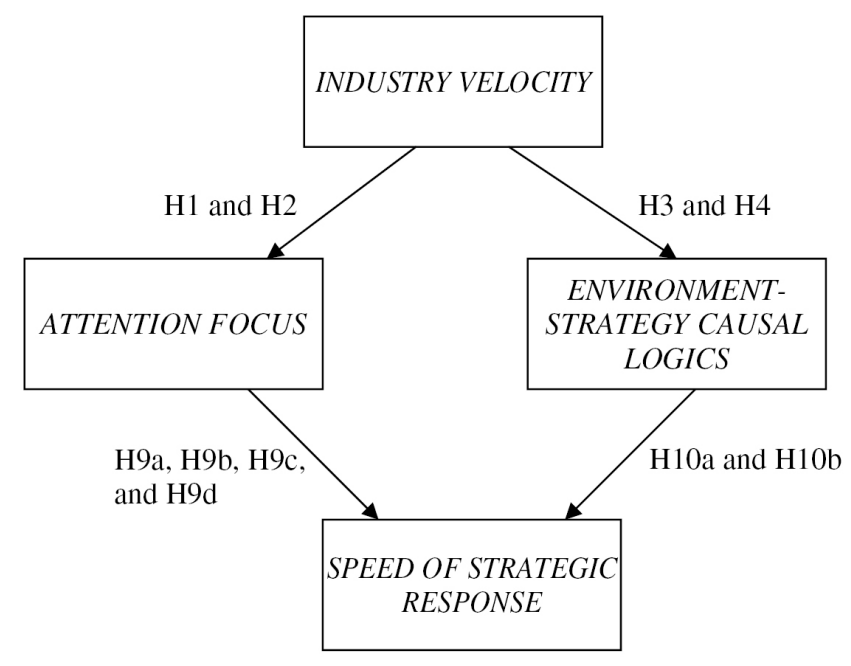

Figure 1. Theoretical model of industry velocity, managerial cognition, and speed of strategic responses

will mediate the relationship between industry velocity and strategic actions. We propose that as top managers make sense of, learn from, and address the unique cognitive challenges embedded in the velocity of their operating environments, they will develop specific attention focus and causal logics about their environments. Further, drawing on the managerial cognition literature (Barr and Huff, 1997; Bogner and Barr, 2000; Chakravarthy, 1982; Cho and Hambrick, 2006; Daft and Weick, 1984; Lant, Milliken, and Batra, 1992; Simon, 1991; Weick, 1995), we propose that top managers' attention focus and causal logics will act as a filter in determining how top managers notice and respond to major environmental changes in their operating environments. Firms will not respond to raw environmental changes unless they notice these variables and interpret how these variables affect their firm. Thus, industry velocity will not affect strategic actions directly; rather attention focus and causal logics will mediate the relationship between industry velocity and strategic actions.

\section{Attention focus and causal logics}

The strategic choice and psychosocial views of organizations (Child, 1972; Weick, 1995) suggest that cognitive limits preclude top managers from developing a complete understanding of their environments (Bogner and Barr, 2000; Daft and Weick, 1984; Fiol and O'Connor, 2003). Instead, top managers de- velop subjective representations of their environment that provide a lens through which they view the current events and activities and make strategic decisions. Thus it is these top managers' subjective cognitive representations, and not the objective environments, that directly affect a firm's strategic priorities and drive decision making. We focus on two forms of subjective representations that top managers develop about their environment-attention focus and environment-strategy causal logics.

\section{Attention focus}

Attention focus refers to the degree to which top managers' subjective representations of their external environment are dominated by concepts related to one (or more) domain over others. Top managers are bombarded with a vast amount of strategic information that often exceeds their cognitive capacity (Simon, 1991). One way to deal with this cognitive overload is through the process of selective attention. Top managers focus their attention on those domains that they deem to be most relevant while selectively ignoring others (Bogner and Barr, 2000; Daft and Weick, 1984; Fiol and O'Connor, 2003; Hambrick and Mason, 1984; Starbuck and Milliken, 1988). Attention focus is important because it provides a filter through which top managers identify issues.

Despite its importance, attention focus remains under-researched. Most literature in this area is theoretical and highlights the impact of firm context (Cho and Hambrick, 2006; Ocasio, 1997) and past performance (March and Shapira, 1992) on the attention focus of managers. For example, Ocasio (1997) theorized that firms' communication and procedural channels (e.g., action memoranda, personnel evaluation, budgetary and capital appropriations requests) affect the attention of decision makers. Cho and Hambrick (2006) examined the mediating effects of attention patterns in the relationship between top management characteristics and strategic change. In their simulation study, March and Shapira (1992) found that firm resources and past performance affect the attention focus of firms. The impact of environment on attention focus has not been addressed in previous research, despite the fact that the relationship between strategy and external environment is highlighted as a central feature in strategy research. 
Attention focus can be directed toward the external environment (e.g., competition, regulations, macroeconomic factors, technology) or internal organizational context (e.g., organizational structures, resources, policies and procedures, communication channels). In this study, we examine attention focus directed toward the external environment. Top managers' attention focus toward external environment is important because it influences the degree of mindful attention that will be directed to a given environmental event (Weick, 1995) and determines the likelihood that any given environmental event will make it onto the firm's strategic agenda and will be responded to (Dutton and Jackson, 1987).

The strategy literature has identified two sectors of environment to which firms attend - task and general (Bourgeois, 1980; Daft, Sormunen, and Parks, 1988; Garg, Walters, and Priem, 2003). The task sector includes those aspects of the environment that have direct transactions with the firm such as competitors, suppliers, and customers, while the general sector includes more macro-level dimensions such as social, demographic, economic, and political. Previous studies show that top managers differ in their relative emphasis on each sector in strategic decision making (Bourgeois, 1980; Daft et al., 1988), thereby highlighting the usefulness of this dichotomy for examining attention focus in subjective representations of the environment. Moreover, differences in attention focus across these two sectors have been found to have implications for strategic action (Garg et al., 2003).

\section{Environment-strategy causal logics}

Causal reasoning is the primary basis for decision making in general (Fiske and Taylor, 1991) and has been found to influence the way in which strategic decisions are made, understood, and communicated (Huff, 1990). Of particular importance to strategic decision making are top managers' beliefs regarding the causal relationship between environment and strategy. In the course of decision making, top managers generate beliefs that relate various environmental and strategy concepts together in a causal manner. These cause-effect beliefs about the environment-strategy relationship frame specific strategic issues and affect how they are interpreted and what strategic actions are initiated (Barr, Stimpert, and Huff, 1992; Barr and Huff,
1997; Dutton, Fahey, and Narayanan, 1983; Eden, Ackermann, and Cropper, 1992; Priem, 1994; Stubbart, 1989). In short, raw signals from the environment are not addressed until top managers interpret their causal relationship with the firm (Huff, 1990; Dutton et al., 1983).

Daft and Weick (1984) differentiate between environment-driven and interpretation-driven causeeffect beliefs about the environment. In environment-driven frames, top managers experience environments as concrete, hard, measurable, and determinant. They therefore first seek to identify environmental demands and then develop strategies in response to them. Top managers thus assume the environment to determine strategy. Such environment $\rightarrow$ strategy beliefs represent deterministic logics (Fahey and Narayanan, 1989). On the other hand, top managers of firms confronting more unstable or unanalyzable environments are thought "to construct, coerce, or enact a reasonable interpretation that makes previous action sensible" (Daft and Weick, 1984: 287, emphasis added). Thus, they attempt to construct their environments through their strategies rather than developing strategies in response to environments (Lyles and Schwenk, 1992), resulting in strategy $\rightarrow$ environment beliefs, or proactive logics (Fahey and Narayanan, 1989).

\section{Industry velocity, attention focus, and causal logics}

Extant research contends that subjective cognitive representations that top managers develop about their environments are the result of making sense of, learning from, and addressing the unique cognitive challenges embedded in their operating environments (Daft and Weick, 1984; Fiske and Taylor, 1991; Reger and Palmer, 1996; Osborne, Stubbart, and Ramaprasad, 2001). For example, Bogner and Barr (2000) argued that through the process of making sense of and responding to the cognitive challenges embedded in the hypercompetitive environments, top managers in hypercompetitive industries develop cognitive representations that are significantly different from those held by top managers from firms operating in more stable environments. Further, empirical evidence suggests that managerial perceptions may vary across industry contexts (Keats and Hitt, 1988; Lant et al., 1992; Priem, 1994; Snyder and Glueck, 1982; Sutcliffe and Huber, 1998), which implies that industry context may in- 
fluence the cognition of top managers. However, the link between industry context and cognition of top managers has not been explicitly tested in a systematic way.

One facet of industry context that has created much interest in both the academic and practitioner-oriented literature on strategic management is industry velocity (Bourgeois and Eisenhardt, 1988; Brown and Eisenhardt, 1997; Eisenhardt and Martin, 2000), variously referred to as industry cycle (Williams, 1994), and industry clockspeed (Fines, 1998). Industry velocity reflects the speed (frequency of changes and the time span of intervals between these changes) (Duncan, 1972; Jurkovich, 1974; Tung, 1979) and unpredictability of changes in industry variables (Brown and Eisenhardt, 1997; Eisenhardt and Martin, 2000). High velocity industries are characterized by rapid and unpredictable changes in product and process technologies and competitors' strategic actions that make it difficult for top managers of incumbent firms to develop a clear and comprehensive understanding of their environment. In contrast, the inherent stability of low velocity industries allows top managers in incumbent firms to gradually build and improve their understanding of the environment through systematic scanning approaches. Thus, high and low velocity industries pose different cognitive challenges to top managers in incumbent firms.

We propose that the differences in cognitive challenges embedded in high and low velocity industries will lead to differences in the nature of interactions and learning that top managers in incumbent firms engage in and result in different forms of attention focus and causal logics held by top managers of firms in high and low velocity contexts. These differences in attention focus and causal logics will, in turn, affect how quickly they respond to major environmental changes. In other words, top managers' attention focus and causal logics will act as filters and mediate the relationship between industry velocity and speed of strategic response.

In this section, we integrate the managerial cognition literature (Bogner and Barr, 2000; Daft and Weick, 1984; Dutton et al., 1983) and the industry velocity literature (Brown and Eisenhardt, 1997; Eisenhardt and Martin, 2000; Fines, 1998) to develop hypotheses that link industry velocity with attention focus and causal logics about environment.
Industry velocity and attention focus

Salience is what causes some environmental cues to draw more attention than others. Research on cognition, including cognition in organizations, demonstrates that the level of salience of any given social cue is linked to the degree to which it is novel in context, deviates from expectations, or is goal relevant (Fiske and Taylor, 1991; Sutcliffe and Huber, 1998). Thus, elements of the operating environment that are expected to capture the attention of top managers are those that are unusual for the environment (e.g., a new competitor in an industry with high barriers to entry), that differ from managerial expectations (e.g., an unanticipated drop in customer demand), or that are perceived as relevant to the attainment of organizational goals (especially elements perceived as significant to organizational performance). Theoretical and empirical work in the strategy and organizations literatures make a similar argument-environmental sectors characterized by strong cues in the form of high levels of uncertainty (unusual for environment or different from expectation) (Daft et al., 1988; Duncan, 1972; Garg et al., 2003), and hostility (goal relevance) (Daft and Weick, 1984) draw the attention of top managers. For example, Daft et al. (1988) found that when sector uncertainty was high, executives reported greater frequency of scanning (i.e., attention).

We expect task sector to be less salient in low velocity environments than in high velocity industries. This is because in low velocity task sectors, changes occur along roughly predictable and linear paths (Bogner and Barr, 2000; Eisenhardt and Martin, 2000). They have relatively stable industry structures such that market boundaries are clear and the players (e.g., suppliers, competitors, customers, complementers) are well known and rarely change so top managers in incumbent firms rarely face task sector events that are unusual or unexpected. The top managers of firms in low velocity industries also face relatively less hostile task sectors because their firms can protect existing core competencies and achieve sustainable competitive advantage by building isolating mechanisms that retard imitations (Garg et al., 2003; Williams, 1994).

In contrast to low velocity environments, the task sectors in high velocity environments are characterized by nonlinear and unpredictable changes (Bog- 
ner and Barr, 2000; Eisenhardt and Martin, 2000). In high velocity industries, market boundaries are blurred, successful business models are unclear, and market players (i.e., buyers, suppliers, competitors, complementers) are ambiguous and shifting (D'Aveni, 1994). Top managers of firms in high velocity environments also face high levels of competitive hostility; building sustainable competitive advantage is difficult because firms cannot protect existing products and processes for a long time (Eisenhardt and Martin, 2000; Fines, 1998; Williams, 1994) and, therefore, firms cannot sustain above-average profits based on a single established innovation or advantage. As top managers of firms in high velocity environments consistently address the fast changing, hostile, and unpredictable changes in the task sectors by introducing new products and/ or process technologies faster (Nerkar and Roberts, 2004; Cottrell and Nault, 2004) and carry out frequent strategic and organizational changes (Eisenhardt and Martin, 2000; Eisenhardt, 1989; Fines, 1998), task sector cues are likely to dominate subjective representations of their operating environment. In sum the stronger salience of task sector in high velocity environments is likely to result in greater dominance of task sector concepts in subjective representations of the environment, whereas the weaker salience of the task sector in low velocity environments will lead to lower levels of attention focus on task sector in managers' subjective representations. We therefore expect that:

Hypothesis I $(\mathrm{HI})$ : Industry velocity will positively affect top managers' attention focus on the task sector.

Due to the predictability and stability of the task sector in low velocity environments, top managers are likely to direct their attention to changes in general sector (such as recession, wars, regulatory, and political), which they may consider to be less predictable and linear. Thus, general sector is likely to create greater levels of uncertainty and hostility than do changes in their task sector (Garg et al., 2003) and to motivate top managers to direct their time and effort toward scanning it. As these managers consistently direct their scanning activities toward the general sector, they will, over time, develop an attention focus bias toward it (Dearborn and Simon,
1958; March and Simon, 1958). On the other hand, the general sector is likely to be less salient than the task sector for top managers of firms in high velocity environments due to the high level of uncertainty and change in the task sector. The weaker salience of the general sector is likely to lead top managers in high velocity environments to direct less attention to it. In other words, all things being equal, the subjective representations top managers of firms in low velocity environments hold of their environments are likely to have direct greater attention focus on general sector than those of firms in high velocity environments.

Hypothesis $2(\mathrm{H} 2)$ : Industry velocity will negatively affect top managers' attention focus on the general sector.

\section{Industry velocity and strategy-environment causal logic}

Daft and Weick (1984) suggest that the degree to which strategy-environment causal logics held by top managers are proactive (strategy $\rightarrow$ environment) or deterministic (environment $\rightarrow$ strategy) is at least partly a function of the nature of the industry itself. Of particular influence is the degree to which environments are predictable or analyzable in the form of well-defined trends in customer demands and clearly defined industry structures. Where "predictable uniformities in relationship among significant objects" exist and accurate forecasts are available, top managers view the environment as "analyzable" and develop strategies that fit their environment (Daft and Weick, 1984: 287). In environments where relationships are less predictable, top managers experience the environment as "unanalyzable" and seek "to construct, coerce, or enact a reasonable interpretation that makes previous action sensible and suggests some next steps" (Daft and Weick, 1984: 287).

High velocity environments reflect rapid, frequent environmental change that continually disrupts the competitive structure of the industry (D'Aveni, 1994; Eisenhardt, 1989). Forecasts are not possible and statistical trends do not correlate with key strategy indicators (Aguilar, 1967). Further, traditional anchors of sense-making such as well-defined competitors, established channels of distribution, and customer groups do not exist (Bogner and Barr, 2000). In these 
industries, top managers actively seek to make sense of their environment by engaging in action and seeing what happens (Weick, 1995). They experiment, test, and probe (Eisenhardt, 1989). As top managers of these firms actively construct and enact their environments through experimentation and innovative strategies, they are likely to develop proactive logics (strategy $\rightarrow$ environment).

In contrast, low velocity environments are characterized by linear and predictable changes (Eisenhardt and Martin, 2000; Fines, 1998; Williams, 1994), which lend themselves well to learning about the nature of the environment and its relationship to firm behavior (Daft and Weick, 1984). Further, clearly established and well-defined industry and competitive structures in the form of competitors, channels of distribution, product markets, and so on exist and remain relatively invariant. Since unpredictable changes in these industries are less frequent, top managers of incumbent firms are likely to view the environment as analyzable and something that firms need to adjust to. Therefore, as top managers of firms in low velocity industries systematically analyze, learn from, and respond to their operating environments, they are likely to develop more deterministic causal logics (environment $\rightarrow$ strategy).

Hypothesis $3(\mathrm{H} 3)$ : Industry velocity will positively affect the level of top managers' proactive causal logics.

Hypothesis $4(\mathrm{H} 4)$ : Industry velocity will negatively affect the level of top managers' deterministic causal logics.

\section{The mediating role of attention focus and causal logics}

In this section, we propose that top managers' attention focus and causal logics will mediate the relationship between environment and strategic action outcomes. We also hypothesize the nature of the mediation. We use speed of strategic response as a strategic action outcome because its implications for firm survival and success make it an outcome of interest for strategy scholars. The strategy literature has consistently prescribed the importance of aligning firm strategies with opportunities and threats in the environment (Andrews, 1987; Ginsberg, 1988; Miles and Snow, 1972; Mintzberg, 1972; Porter,
1985; Quinn, 1980; Hofer and Schendel, 1978). Further, research has demonstrated that firms that initiate timely strategic responses to changes in the environment outperform those that delay in their response (Cotrell and Nault, 2004; Haveman, 1992; Nerkar and Roberts, 2004; Smith and Grimm, 1987; Baum and Wally, 2003). Studies have also shown that firms that fail to adjust in a timely fashion may enter a downward spiral from which they do not escape (Cameron, Sutton, and Whetten, 1988; Hambrick and D'Aveni, 1988).

Cognition studies have argued that the initiation of speedy firm responses to environmental changes is tied to top managers' interpretations of the environment (Barr and Huff, 1997; Bogner and Barr, 2000; Chakravarthy, 1982; Daft and Weick, 1984; Lant et al., 1992; Simon, 1991; Weick, 1995). Dutton and Duncan (1987) suggest that “... a major reason organizations respond differently to changes in the environment involves how strategic issues are triggered and interpreted by decision-makers" (Dutton and Duncan, 1987: 279). As cognitive limits preclude top managers from forming complete and accurate understandings of their environment, it is top managers' subjective cognitive interpretations of the environment, rather than the objective nature of the environment itself, that determines which external events will be noticed and responded to. Raw signals from the environment are not addressed until firms notice these signals and interpret their causal relationship with the firm (Huff, 1990; Dutton et al., 1983). This suggests that industry velocity will not have a direct effect on the speed of response. Rather, attention focus and causal logics will affect which environmental events top managers notice, how they interpret those events, and how quickly they respond to them. In other words, attention focus and causal logics will mediate the relationship between industry velocity and the speed of response. Hypothesis 5 (H5): Attention focus on the general sector will mediate the relationship between industry velocity and speed of response to changes in the general sector and the task sector.

Hypothesis $6(\mathrm{H} 6)$ : Attention focus on the task sector will mediate the relationship between industry velocity and speed of response to changes in the general sector and the task sector. 
Hypothesis $7(\mathrm{H} 7)$ : Proactive causal logics will mediate the relationship between industry velocity and speed of response to changes in the general sector and the task sector.

Hypothesis 8 (H8): Deterministic causal logics will mediate the relationship between industry velocity and speed of response to changes in the general sector and the task sector.

In what follows, we specify the nature of mediation of attention focus and causal logics.

\section{Attention focus}

Top managers are more likely to recognize and actively attend to environmental change that takes place in the sectors that are central to their subjective representations of the environment than to changes that occur in the sectors that are less central to their representations (Lant et al., 1992; Fiol and O'Connor, 2003). When top managers fail to actively attend to environmental changes, they are unlikely to implement strategic responses (Huff and Schwenk, 1990; Terreberry, 1968). Further, top managers are likely to more quickly recognize, understand, and formulate responses to changes in the sectors to which they actively attend than to changes in sectors that are not central to their cognitive systems. Therefore, firms with top managers that have an attention focus on the general sector are more likely to quickly recognize and actively attend to changes in this sector than changes in the task sector. Conversely, top managers' strong attention focus on task sector is likely to promote faster response to changes in the task sector. This suggests the following hypotheses:

Hypothesis 9a (H9a): Top managers' attention focus on the general sector will be positively related to speed of response to changes in the general sector.

Hypothesis 9b (H9b): Top managers' attention focus on the general sector will be negatively related to speed of response to changes in the task sector.

Hypothesis 9c (H9c): Top managers' attention focus on the task sector will be positively related to speed of response to changes in the task sector.
Hypothesis 9d (H9d): Top managers' attention focus on the task sector will be negatively related to speed of response to changes in the general sector.

\section{Environment-strategy causal logics}

Speed of response is also likely to be influenced by the type of causal logics top managers hold about the relationship between environment and firm behavior. Top managers with deterministic causal logics undertake action to realign the environment-strategy fit following a change in their task or general sectors. After the environmental change occurs, top managers with deterministic causal logics will first try to understand what the events mean in terms of change in environmental demands so they can develop a proper "fit" response, and response will follow (Wooldridge and Floyd, 1989). Developing a comprehensive understanding of a specific environmental change requires extensive intelligence gathering and market surveillance activities (Daft and Weick, 1984; Wooldridge and Floyd, 1989), which requires significant time and resources. This emphasis on getting feedback from specific environmental changes before undertaking response actions is therefore expected to decrease the speed of strategic response to environmental changes in both the task sector and the general sector.

Top managers with proactive causal logic do not undertake extensive efforts to understand their environments prior to undertaking a response. Top managers will undertake actions based on their own interpretations; sense-making processes about the event follow rather than precede action (Daft and Weick, 1984). Top managers with proactive causal logics experiment, test, and probe the environment through action (Chakravarthy, 1982; Daft and Weick, 1984; Eisenhardt and Martin, 2000) and action outcomes provide feedback about the environmental changes. This proactive and anticipatory adaptation will considerably increase the speed of strategic responses initiated by firms in high velocity industries.

Hypothesis I Oa ( $\mathrm{HIOa})$ :Top managers' deterministic environment-strategy causal logics will be negatively related to speed of response to both the general sector and the task sector. 
Hypothesis I Ob ( $\mathrm{H} \mid \mathrm{Ob})$ :Top managers' proactive environment-strategy causal logics will be positively related to speed of response to both the general sector and the task sector.

\section{Methods}

\section{Choice of industries}

To test our hypotheses, we needed to identify industries that varied in velocity but were similar on other dimensions that could confound attention focus, causal logic, and speed of response. Accordingly, we selected industries using a two-step process: First, based on a thorough review of existing literature on industry velocity (Bourgeois and Eisenhardt, 1988; Eisenhardt, 1989; Brown and Eisenhardt, 1997; D'Aveni, 1994; Fines, 1998; Judge and Miller, 1991; Mendelson and Pillai, 1999; Williams, 1994), we identified seven high velocity (personal computers, computer software, toys and games, athletic footwear, semiconductors, movie, and cosmetics) and six low velocity (aircraft, furniture, steel, ship building, petrochemicals, and paper) industries.

Second, we matched each high velocity industry with every low velocity industry on nine objective and four subjective industry attributes that could potentially confound our results. Objective measures included: capital intensity, R\&D intensity, advertising intensity, total shipments, employment, exports, imports, industry concentration, and munificence (Dess and Beard, 1984). We measured these variables using industry-level data from COMPUSTAT and U.S. Industry Outlook data published by U.S. Department of Commerce (1993). For subjective measures, we used the average ratings (based on a five-point Likert scale) of one industry analyst and two strategy professors (Kippendorf's alpha = 0.89) familiar with each industry on four industry attributes: knowledge intensity, manufacturing intensity, complexity of supply chain, and technology intensity (hi-tech versus low-tech) (Fines, 1998; Ghemawat and Rivkin, 1999). We computed the Euclidean distances for each industry pair (high velocity-low velocity) and chose two pairs that had the minimum distance: semiconductor-aircraft and cosmetic-petrochemicals. The use of four industries (two matched pairs) allowed us to isolate the impact of industry velocity on cognition and strategic response variables, while minimizing the confounding effects of differences across the four industries in industry attributes other than industry velocity.

\section{Time frame and sample selection}

We chose a 25-year period - 1970 to 1994 -for this study. Prior work indicates that 25 years is sufficient to capture the upturns and the downturns in the performance, growth, technologies, and global competition of the four industries studied here (Bilstein, 1996; Chapman, 1991; Estrin, 1984; Heppenheimer, 1997).

We used three criteria to select firms from the four industries (four-digit Standard Industrial Classification codes). First, strategy studies have stressed that it is important to select nondiversified firms in studies making cross-industry comparisons because the effects of industry characteristics (such as industry velocity) on cognition (Huff, 1982) and strategy variables (Gupta, 1988; Rajagopalan and Datta, 1996) can be more directly assessed for nondiversified firms. Hence, we restricted our sample to firms deriving at least 70 percent of their sales revenues (Rumelt, 1974) from their primary business for the entire time period of the study (1970-1994). Second, strategy studies have underscored that relationships between industry characteristics and individual firm behavior are likely to be most pronounced for the large, principal firms in an industry (Rajagopalan and Datta, 1996; Williamson, 1963). We used three measures of firm size used most frequently in previous literature to identify the largest firms in the four industries from 1970 to 1994-natural logarithm of the number of employees in the firm (Dalton and Kesner, 1983; Guthrie and Olian, 1991), total firm sales in dollars (Rajagopalan and Datta, 1996), and market share (Porter, 1985). Third, variation in attention focus and causal logics and speed of response can result from maturation of firms rather than from variation in the industry velocity. This problem is more likely in younger rather than older firms (Baron and Bielby, 1980). Firms that are at least 10-years old are adequately mature (Baron and Bielby, 1980) and have well developed cognition (Barr, 1998), so we selected firms that were at least 10-years old.

These diversification, size, and age measures yielded seven firms in the aircraft industry, seven firms in the semiconductor industry, five firms in 
the petrochemical industry, and five firms in the cosmetic industry. Appendix I lists the sample firms and provides basic demographics on each.

\section{Data sources}

Measuring top managers' cognition is a difficult task; cognitive structures cannot be measured directly and the very act of asking individuals to reveal their beliefs can change them. This is particularly problematic when asking individuals to recall the beliefs they held in prior time periods because memories are often incomplete, misinterpreted, or mistakenly reported because of the outcomes later achieved (Bettman and Weitz, 1983). The retrospective bias inherent in interviews is particularly problematic in situations where individuals are asked to recall information from the distant past, as would be the case for the type of longitudinal design used in the present study (Golden 1992).

Prior work has addressed these issues by utilizing written or verbal statements as indirect indicators of top managers' beliefs or subjective cognitive representations (Barr et al., 1992; Davis, Diekmann, and Tinsley, 1994; Fiol, 1994). Of particular relevance to those interested in capturing the beliefs of the top management of an organization are Letters to Shareholders (LTS) in company annual reports. These letters are public statements made by chief executives charged with charting their companies' futures and are official documents that discuss the strategic themes that top managers believe are important to the firm (Osborne et al., 2001). While these documentary sources can represent only espoused beliefs rather than the full complement of beliefs that are held, perhaps unconsciously (Fiske and Taylor, 1991), by top managers, there is reason to believe that they reflect those beliefs that are at the forefront of their consciousness as they contemplate the issues of the time (Erdener and Dunn, 1990). Thus, these documents allow one to capture indicators of top managers' beliefs in use while avoiding the unintentional imposition of the researcher's own beliefs about what concepts should be important. Researchers have used LTS to identify corporate strategies (Bowman, 1978; Miller et al., 1996), assess the causal reasoning of strategic decision makers (Barr et al., 1992; Bettman and Weitz, 1983; Fahey and Narayanan, 1989), examine how institutional changes are theorized (Greenwood, Suddaby, and Hinnings, 2002) and how changes in industry regulations are interpreted (Barr, 1998; Barr and Huff, 1997), and explain cognitive bases of joint venture activity (Fiol, 1989).

A major criticism of the use of LTS is that they are written for specific audiences and thus may suffer from attempts at impression management. Previous studies have found this self-serving bias to be most relevant to statements explaining firm performance-managers attribute positive organizational outcomes to internal causes and negative outcomes to external causes (Bettman and Weitz, 1983; Staw, McKechnie, and Puffer, 1983; Salancik and Meindl, 1984). However, more recent work suggests that these attribution patterns may represent biases in the sense-making process, not conscious attempts at impression management (Huff and Schwenk, 1990; Clapham and Schwenk, 1991).

Comparisons between the framing in LTS and framing in internal documents have revealed that statements concerning non-evaluative issues such as control, internal/external orientation, and customer orientation were highly consistent across internal and external sources (Fiol, 1995). Because our study is interested only in the relative focus of representations on different environmental sectors and on the direction of the environment-strategy relationship, evaluative statements are irrelevant to the study and we excluded evaluative statements, which specify a clear positive (e.g., the economic boom has improved our financial position and given us a competitive edge) or negative evaluation (e.g., the economic downturn created a crisis for our firms) of a specific environmental event on firm outcomes. We focused instead on neutral and non-evaluative statements that mentioned specific strategic actions that firms undertook to respond to environmental events (e.g., industry sales dropped by $15 \%$... so we cut costs by $20 \%$ by closing down four factories and selling old machinery and equipment). As a result, we expect that statements in LTS give us a reasonable reflection of the espoused beliefs held by top managers from our sample firms. To further assess the appropriateness of this data source, we conducted checks for consistency, trustworthiness, and time lag, as follows:

\section{Consistency}

It is possible that the role played by top managers in preparing LTS is limited and so what is reflected 
there is not consistent with the beliefs held by those managers. However, informal conversations with executives (Barr et al., 1992) and systematic empirical analyses (Fiol, 1994) suggest considerable top management involvement and accuracy in the preparation of LTS. Clapham and Schwenk (1991) also suggest that LTS are closely scrutinized by financial analysts and are therefore too important to be ignored by top managers. Nevertheless, to check the consistency of the content of these documents, we compared their content to the management's discussion and analysis section of the $10-\mathrm{K}$ forms for our sample firms over the entire study period. Considered to be a good validation source because their contents are believed to have high reliability (Glueck and Willis, 1972), 10-K forms are not created as means of public communication but rather are written to fulfill Security and Exchange Commission filing requirements. In our analysis, the percentage of common concepts between LTS and management's discussion ranged from 60 percent to 77 percent (semiconductor industry: mean $=68 \%$, S.D. $=12 \%$; aircraft industry: mean $=71 \%$, S.D. $=15 \%$; cosmetic industry: mean $=74 \%$, S.D. $=10 \%$; petrochemical industry: $67 \%$, S.D. $=15 \%$ ), suggesting satisfactory consistency in content between the two documents (Carley and Palmquist, 1992). We also found high correlations (ranging from $0.47, p<0.05$ to $0.74, p<$ 0.0001 ) between the frequencies of concepts appearing in the LTS and in management's analysis, suggesting consistency in the relative emphasis given to different concepts across the two documents (Carley and Palmquist, 1992).

\section{Trustworthiness of information}

We asked two industry analysts to rate each of the 24 sampled companies for the level of trustworthiness of information disclosed in the LTS on a five-point scale ( $1=$ highly untrustworthy and 5 $=$ highly trustworthy) for five different time periods (1970-1975, 1975-1980, 1980-1995, 1985-1990, 1990-1994). The analysts were asked to focus on misrepresentation of facts as well as framing of the information. None of the 24 sampled firms received a rating of "untrustworthy" or "highly untrustworthy" for the period of our study. The mean of the trustworthiness ratings was 3.9 and the standard deviation was 0.90 .
Time lags

Expression in an LTS may lag considerably behind an actual strategic action. To check for such lags, we collected announcements of 15 specific events (e.g., mergers, acquisitions, divestiture) made by the firms in The Wall Street Journal (1970-1994) and then matched the date of an announcement with the mention of the same event in the LTS. A time lag existed if the event was not reported in the LTS for the same year as the event was announced in The Wall Street Journal. None of the firms had time lags for more than 15 percent of the events in the 25 years. Thus, time lag was not an issue for the current sample.

\section{Constructing causal maps}

To measure attention focus and causal logics of top managers, we first elicited top managements' causal maps of their environments from annual reports. The causal mapping technique is a form of content analysis that isolates causal assertions within a document (Axelrod, 1976). Use of causal mapping is consistent with the assertion that causal reasoning is the primary way in which strategic decisions are developed and understood (Barr et al., 1992; Huff, 1990). As noted earlier, content analysis of archival documents is especially useful in our study because it avoids the recall bias that plagues interviews (Axelrod, 1976) especially when, as in this case, the study covers longitudinal time frames. Moreover, causal mapping provides detailed, rigorously collected information about cognitive structures that is not typically found in case studies (Barr, 1998).

Following Axelrod (1976), we developed causal maps from the LTS in a four-step procedure illustrated in Appendix II. In the first step, two raters (not authors) familiar with the area of strategic management independently identified statements that clearly contained a cause-effect relationship between environment and strategy variables from the LTS using key words such as "if-then," "because," "so," "as." We did not provide any formal definitions of "environment" and "strategy" to the raters to minimize intrusiveness in eliciting raw phrases (Barr et al., 1992; Fahey and Narayanan, 1989). We assessed their interrater reliability using Kendall's coefficient of concordance $(\mathrm{W}=0.88)$. 
In the second step, raw causal maps were created. This process involves deciding which part of the text to code, and what words to use in the coding scheme. To identify which part of the text to code, the same two raters separated the causal statements identified in the first step into "causes" and "effects" to build the "raw causal maps." Carley and Palmquist (1992) argue that aggregation reduces misclassification of concepts due to peculiar wording by individuals, so to decide what words to use in the coding scheme, three experienced coders (not authors or original coders) independently coded the original cause and effect phrases in the LTS identified by the two raters into 48 common "raw environmental concepts" and 59 "raw strategy concepts" $(\mathrm{W}=0.91)$ that were close in meaning to the original phrases in the annual reports. To avoid coder bias, text distortion and comparative incongruence, the coders used the rule "denotation rather than interpretation." We used the "majority rule" to resolve disagreements between the coders (Carley and Palmquist, 1992). We also consulted industry and strategy experts to ensure the 107 raw concepts were distinctive and at the same level of abstraction.

In the third step, we used existing theoretical frameworks to organize the 107 raw concepts into broad conceptual categories representing environment and strategy. Generalization of similar concepts using theoretical frameworks enables researchers to set up a common basis to compare causal maps across diverse topical contexts (e.g., high and low velocity industries) and increases the relevance and validity of the emergent concepts by ensuring that the categories are distinct and uniform in breadth and abstraction (Carley and Palmquist, 1992; Fahey and Narayanan, 1989).

To categorize environmental concepts, we used extant frameworks of the general and task sectors (Bourgeois, 1980; Daft et al., 1988; Garg et al., 2003). We classified concepts relating to macroeconomic (e.g., domestic recession, global recession, international currency exchange rates, and Asian financial crises), political (e.g., change in political administration, change in government policies, changes in world trade organization policies, European Union charter, and international U.S. relations), and regulatory variables (e.g., environmental laws relating to reduction in noise and pollution levels) under the general sector. We grouped concepts relating to competition (e.g., imitators, new entrants, decline in barriers to entry, global competition, cooperative al- liances of competitors), supplier (e.g., scarcity of raw materials, supplier dominance, diversity of suppliers), customer (e.g., market fragmentation, growth of specific markets, convergence of markets, shifts in customer demand), and technology (e.g., product innovation, diffusion of technological know-how, technological transitions) under the task sector. We show our coding list in Appendix III.

Organizational strategy consists of both content (the "what" of strategy) and process (the "how" of strategy) and we sought to include indicators of both in this study. We used prominent strategy content (Porter, 1985; Rumelt, 1974) and process (Mintzberg, 1972; Reger and Huff, 1993) frameworks to comprehensively categorize firm strategies mentioned in the LTS. We used Porter's (1985) contentbased framework to organize corporate strategy concepts and the competitive action classification (Ferrier, 2001; Ferrier, Smith, and Grimm, 1999) to organize competitive strategies. We used a variety of sources including popular text books (Hitt, Ireland, and Hoskisson, 2004), classic books (Hofer and Schendel, 1978), and process related review (Reger and Huff, 1993) and empirical (Mintzberg, 1972) papers to develop a comprehensive classification of strategy process concepts.

We validated these environmental and strategy categories using the sorting technique suggested by Anderson and Gerbing (1991). Three strategy professors and four industry analysts classified the 48 environmental concepts into general and task sector categories and the 59 strategy concepts into strategy content and process categories $(\mathrm{W}=0.89)$. We used the majority rule in categorizing concepts for which the agreement was not 100 percent (Carley and Palmquist, 1992) and utilized only those concepts agreed to by four or more raters.

For illustrative purposes, Figure 2 shows parts of the causal maps of a firm in low velocity industry and a firm in high velocity industry.

\section{Measures}

\section{Industry velocity}

Industry velocity comprises both rate (speed) and volatility (unpredictability) of changes in industry variables (Bourgeois and Eisenhardt, 1988; Brown and Eisenhardt, 1997; Eisenhardt, 1989; Eisenhardt and Martin, 2000). We used three established and 


\section{Firm in low velocity industry:}

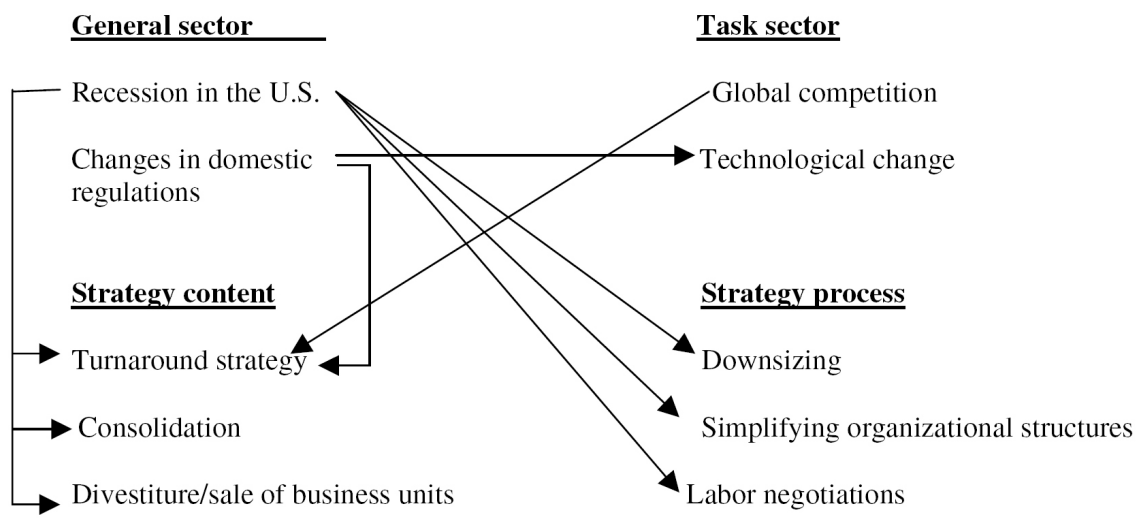

Firm in high velocity industry:

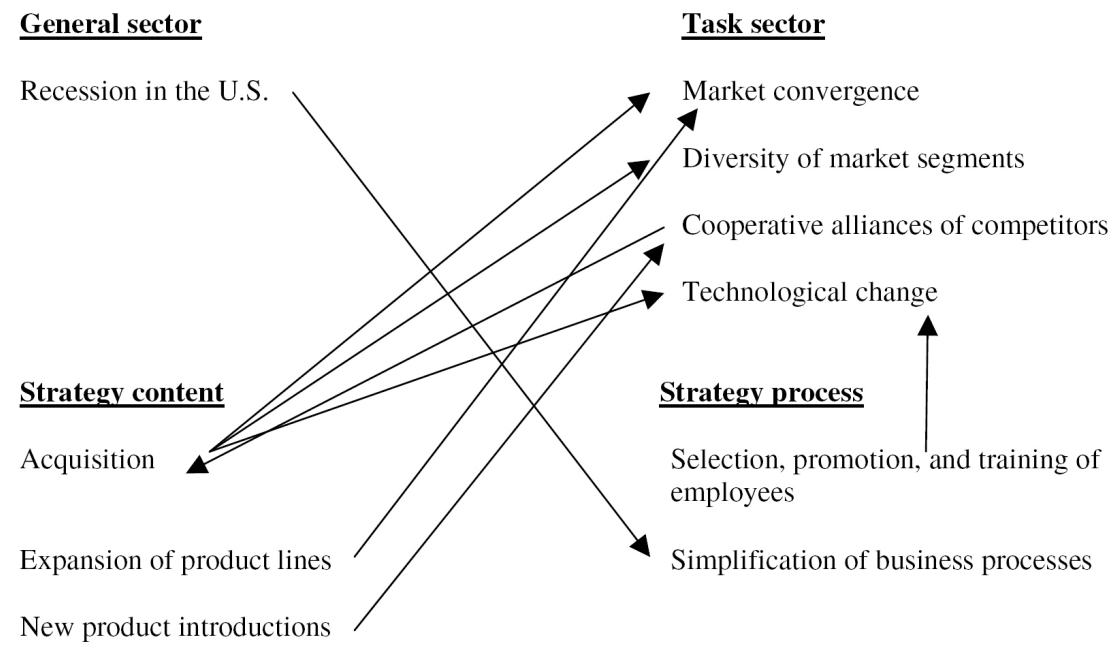

Figure 2. Illustration of parts of the causal maps of a firm in low velocity industry and a firm in high velocity industry

validated measures of rate of industry change: number of new products introduced, time span (number of years) between new products introduced, and depreciation rates of capital equipment (coefficient alpha $=0.92)$ (Fines, 1998; Katila and Ahuja, 2002; Martin and Mitchell, 1998; Mendelson and Pillai, 1999; Nerkar and Roberts, 2004). We used trade and industry-specific journals and manufacturer's catalogs to gather information on the number and number of years between new product introductions. Consistent with previous studies on industry velocity (Fines, 1998; Mendelson and Pillai, 1999) and new product introductions (Katila and Ahuja, 2002; Martin and Mitchell, 1998; Nerkar and Roberts, 2004), we focused on individual products introduced rather than categories of new products introduced. We computed the average depreciation rates for each industry based on the $10-\mathrm{K}$ forms of incumbent firms in the industry. The results of Wilcoxon $^{1}$ sign rank tests confirmed that both semiconductor and cosmetic industries had higher numbers of new product introductions, shorter spans of intervals between new product introductions, and lower

1 The semiconductor industry had higher velocity than the aircraft (new product introductions: $Z=4.53, p<0.001$; span of intervals: $Z=5.95, p<0.001$; depreciation rates: $Z=3.89, p$ $<0.001$ ); and the petrochemical (new product introductions: $Z=5.28, p<0.001$; span of intervals: $Z=5.31, p<0.001)$ industries. The cosmetic industry also had higher velocity than the aircraft industry (new product introductions: $Z=$ $4.15, p<0.001$; span of intervals: $Z=4.79, p<0.001$; depreciation rates: $Z=3.59, p<0.01$ ). Differences in rate of industry change measures of the semiconductor and cosmetic, and the aircraft and petrochemical industries not significant. 
Table 1. Major events in the general sectors of the four industries: 1970 to 1994

\begin{tabular}{|c|c|c|c|c|c|}
\hline \multirow[t]{2}{*}{ Environmental sector } & \multirow[t]{2}{*}{ Type of change } & \multicolumn{4}{|c|}{ Number of changes } \\
\hline & & $\begin{array}{l}\text { Aircraft } \\
\text { industry }\end{array}$ & $\begin{array}{l}\text { Semiconductor } \\
\text { industry }\end{array}$ & $\begin{array}{l}\text { Petrochemical } \\
\text { industry }\end{array}$ & $\begin{array}{l}\text { Cosmetic } \\
\text { industry }\end{array}$ \\
\hline & Macroeconomic & 3 & 3 & 3 & 3 \\
\hline & Political & 3 & 2 & 2 & 2 \\
\hline & Regulatory & 1 & 2 & 3 & 3 \\
\hline \multicolumn{6}{|l|}{ Task sector } \\
\hline & Competitive & $\begin{array}{l}1 \\
2\end{array}$ & 4 & $\begin{array}{l}1 \\
2\end{array}$ & $\begin{array}{l}2 \\
4\end{array}$ \\
\hline & Technological & 1 & 5 & 2 & 4 \\
\hline & Total changes & 4 & 11 & 5 & 10 \\
\hline
\end{tabular}

depreciation rates of capital equipment than aircraft and petrochemical industries for the years 1970 to 1994.

We measured volatility using a variation of the environmental volatility measure developed by Dess and Beard (1984). We calculated volatility by regressing a variable for each year on a variable for net industry sales (Bergh and Lawless, 1998). We ran 25 different equations in each industry to estimate volatility for each of the 25 years (1970-1994). For example, we used net industry sales from 1965 to 1970 to predict volatility in 1970 and so on. Following the equation $y_{t}=b_{0}+b 1_{t}+a_{t^{\prime}}$ where $y$ is industry sales, $t$ is year, and a is the residual, volatility was the standard error of the regression slope coefficient divided by average sales. Larger values of volatility point to greater environmental unpredictability (Bergh and Lawless, 1998; Dess and Beard, 1984). The results of Wilcoxon sign rank tests ${ }^{2}$ confirmed that both the semiconductor and cosmetic industries were more volatile than aircraft and petrochemical industries.

The rate and volatility measures were highly correlated (ranging from 0.64 to 0.88). Therefore, we created a composite measure of industry velocity by averaging the z-scores of rate and volatility measures. We measured the industry velocity measures $(t)$ in the year preceding the year in which we

2 The semiconductor industry had significantly higher volatility than the aircraft $(Z=3.78, p<0.001)$ and the petrochemical $(Z=4.25, p<0.001)$ industries. The cosmetic industry also had significantly higher unpredictability than the aircraft $(Z$ $=3.25, p<0.001)$ and the petrochemical $(Z=4.21, p<0.001)$ industries. Differences in the unpredictability of the semiconductor and cosmetic, and the aircraft and petrochemical industries were not significant. measured the attention focus and causal logic variables $(t+1)$.

\section{Environmental events}

We identified major events in the general and task sectors of the aircraft, petrochemical, semiconductor, and cosmetic industries (Bourgeois, 1980; Daft et al., 1988; Garg et al., 2003). Table 1 shows the number of events identified in the general and task sectors for each industry. For the general sector, we triangulated industry histories (Bilstein, 1996; Chapman, 1991; Estrin, 1984; Heppenheimer, 1997), trade journals and reports (U.S. trade outlook, 1994, 2000), and interviews with industry consultants to identify major events in the macroeconomic (e.g., domestic recession in 1990, Asian financial crisis in 1997), political (e.g., Persian Gulf War in 1991, and changes in bilateral trade agreements between the United States and Japan in 1985 and 1988), and regulatory (e.g., deadlines for completion of phase I and II of reduction in noise and pollution emission levels for aircrafts, upgrading of material standards for the cosmetic industry) arenas of the four industries.

We identified major events in the task sectors of the four industries based on indicators of changes in competitive, customer demand, and technology variables. We used changes in five indicators to identify changes in competition: capital intensity, R\&D intensity, advertising intensity, value of imports, and value of exports. A major decrease in capital intensity, R\&D intensity, and advertising intensity implies that barriers to entry decline significantly, thereby resulting in significant increase in new entrants and competition and/or a major shift 
in competition (Hill and Hansen, 1991). The value of imports and exports represents the degree of global competition in an industry; a major change in either variable suggests a significant shift in the scope of competition (Hambrick and Lei, 1985). We measured shifts in demand through significant changes in industry sales (value of total shipments) (Dess and Beard, 1984). Significant increase or decline in industry growth rate represents major shifts in industry munificence.

We used an auto correlation function (ACF) plot to identify significant changes in the five competition variables and in changes in industry sales (Eye, 1990). An ACF represents correlations of a series with lagged values of itself. It is especially useful in diagnosing outliers or unpredictable values in the time series. Yearly changes in which the standard error values were outside of the 95 percent confidence interval as assessed by the auto correlation function (ACF) were identified as major competitive changes.

Technology changes are also an integral part of a firm's task sector (Tushman and Anderson, 1986; Tushman and Romanelli, 1994). We used Tushman and Anderson's (1986) definition to identify technological shifts - end of an era of convergence and emergence of new technologies that either significantly improve or completely replace existing technologies. A review of industry analysis reports by the U.S. Department of Commerce (1994, 1997) (U.S. Industrial Outlook, 1994, U.S. Industry \& Trade Outlook, 1997) and history books (Bilstein, 1996; Chapman, 1991; Estrin, 1984; Heppenheimer, 1997) on the four industries led us to identify one technological shift in the aircraft industry (19941995: introduction of the revolutionary high-speed civil transport); five shifts in the semiconductor industry (1983-1984: dynamic random access memory (DRAM) technology; 1986-1987: focus on non-DRAM technologies; 1989-1990: erasable programmable memory chips (EPROM) technology; 1993-1994: convergence of computing and communications technologies creating mobile computing and personal conferencing products; and 19971998: introduction of "hybrid applications" such as multimedia applications) (Goldstein and Aspray, 1997; U.S. Department of Commerce, 1993 [Industrial Outlook, 1993: chap. 15]); four shifts in the cosmetic industry (1975-1977: automated cosmetic manufacturing technologies; 1980-1982: shift from metal to laminated plastic packaging technology;
1985-1987: introduction of synthetic base materials; 1992-1994: animal testing alternative technologies); and two shifts in the petrochemical industry (1974-1976: plate tectonic and jet drilling technologies; 1992-1994: basin simulation, 3D seismic and tertiary recovery technologies).

We validated the technology shifts in each industry using one industry analyst and two professors specialized in corresponding industry research. We provided the experts with a list of individual product and process innovations in the industry and asked that they classify them into major and minor innovations from 1970 to 1994. The "major" innovations identified by the experts matched the technology shifts identified through archival sources.

\section{Attention focus}

We measured attention focus by the network-based measures of centrality of the concepts in the LTS. Centrality reflects the degree to which a concept dominates the causal relationships in a cause map; the greater the centrality of a concept, the greater the attention focus around that concept in the map (Carley and Palmquist, 1992; Eden et al., 1992; Knoke and Kuklinski, 1982). We used two network-based measures of centrality - degree (how well connected a given concept is within a network) and closeness (how close a given concept is to other concepts in the network). We computed centrality measures using the Netanalysis software (Fahey and Narayanan, 1989; Nadkarni and Narayanan, 2005), which uses standard social network algorithms (Borgatti, 2005; Freeman, 1978/1979; Knoke and Kuklinski, 1982).

Degree centrality focuses only on direct or adjacent paths of a concept with other concepts in the network. Degree centrality is computed as (Borgatti, 2005; Freeman, 1978/1979; Scott, 2000):

$$
\mathrm{C}_{\mathrm{D}}\left(\mathrm{P}_{\mathrm{k}}\right)=\frac{\sum_{\mathrm{i}=1}^{\mathrm{n}} \mathrm{a}\left(\mathrm{p}_{\mathrm{i}}, \mathrm{p}_{\mathrm{k}}\right)}{\mathrm{n}-1}
$$

where:

$\mathrm{C}_{\mathrm{D}}\left(\mathrm{P}_{\mathrm{k}}\right)=$ number of concepts connected to concept k

$\mathrm{a}\left(\mathrm{p}_{\mathrm{i}}, \mathrm{p}_{\mathrm{k}}\right)=$ connection from $\mathrm{p}_{\mathrm{i}}$ to $\mathrm{p}_{\mathrm{k}}$ (either 0 or 1 )

$\mathrm{n}=$ number of concepts in the causal map

The closeness centrality is obtained by using the shortest paths from the focal concept to reach all 
other concepts in the network as follows (Freeman, 1978/1979; Nieminen, 1974):

$$
\mathrm{C}_{\mathrm{C}}\left(\mathrm{P}_{\mathrm{k}}\right)=\sum_{\mathrm{i}=1}^{n}\left[\frac{\mathrm{d}\left(\mathrm{p}_{\mathrm{i}}, \mathrm{p}_{\mathrm{k}}\right)}{\mathrm{n}-1}\right]^{-1}
$$

where:

$$
\begin{aligned}
& \mathrm{C}_{\mathrm{D}}\left(\mathrm{P}_{\mathrm{k}}\right)=\text { number of concepts connected to } \\
& \text { concept } \mathrm{k}
\end{aligned}
$$

Appendix IV illustrates the degree and closeness centrality measures for a causal map comprising four concepts (A, B, C, and D). Concept C is the most central concept in the network based on degree (1.0) as well as closeness (1.0) centrality because it is most connected and has the shortest distance to other concepts in the network. Following previous studies, we represented centrality of the task or general sector by the centrality score of the most central concept in each environmental sector (Carley and Palmquist, 1992; Eden et al., 1992; Knoke and Kuklinski, 1982). Because the degree and closeness measures of centrality were highly correlated, we created a composite measure of centrality by averaging the $Z$ scores of the two measures. We gathered centrality observations from the LTS for each year from 1970 to 1994 . We lagged the centrality ( $\mathrm{t}$ +1 ) measures a year behind the industry velocity $(t)$ measures.

\section{Proactive and deterministic environment-strategy logics}

The managerial cognition literature has defined deterministic logics as environment $\rightarrow$ strategy links in the causal maps and proactive logics as strategy $\rightarrow$ environment links in the causal maps (Eden et al., 1992; Fahey and Narayanan, 1989). Accordingly, we used in-degree and out-degree analysis (Bougon, Weick and Binkhorst, 1977; Eden et al., 1992; Ford and Hegarty, 1983; Knoke and Kuklinski, 1982) of the causal links between environment and strategy in the causal maps to measure levels of proactive and deterministic causal logic. In-degree refers to the number of direct and indirect causal links going into a concept and is indicative of the degree to which the concept is contingent on a variety of factors influencing it. It is computed as (Freeman, 1978/1979; Scott, 2000):

$$
\mathrm{C}_{\mathrm{DI}}\left(\mathrm{P}_{\mathrm{k}}\right)=\sum_{\mathrm{i}=1}^{n}\left[\frac{\mathrm{DI}\left(\mathrm{p}_{\mathrm{i}}, \mathrm{p}_{\mathrm{k}}\right)}{\mathrm{n}-1}\right]^{-1}
$$

where:

$$
\begin{aligned}
& \mathrm{C}_{\mathrm{DI}}\left(\mathrm{P}_{\mathrm{k}}\right)=\text { number of concepts going into concept } \\
& \mathrm{NI}\left(\mathrm{p}_{\mathrm{i}^{\prime}} \mathrm{p}_{\mathrm{k}}\right)=\text { distances: shortest number of paths } \\
& \text { through which concepts in the network } \\
& \text { go into concept } \mathrm{p}_{\mathrm{k}} \\
& \mathrm{n}=\text { number of concepts in the causal map }
\end{aligned}
$$

A high number of in-degrees for strategy concepts would suggest that firms consider strategy as primarily an effect of, or response to, environmental concepts in the map representing a deterministic causal logic. Appendix IV shows that concepts $\mathrm{C}$ and $\mathrm{D}$ have high in-degrees, whereas concepts $\mathrm{A}$ and $\mathrm{B}$ have zero in-degrees.

For our study, high number of in-degrees for environmental concepts would suggest that strategies influence the environment and thus represents proactive causal logic, whereas the in-degrees for strategy concepts would suggest that environment affects strategies, suggesting a deterministic causal logic.

Out-degree refers to the number of links going out of a concept and is indicative of the degree to which a concept influences other concepts in the frame. Out-degree is computed as follows (Freeman, 1978/1979; Scott, 2000):

$$
\mathrm{C}_{\mathrm{DO}}\left(\mathrm{P}_{\mathrm{k}}\right)=\sum_{\mathrm{i}=1}^{n}\left[\frac{\mathrm{DO}\left(\mathrm{p}_{\mathrm{i}}, \mathrm{p}_{\mathrm{k}}\right)}{\mathrm{n}-1}\right]^{-1}
$$

where:

$\mathrm{C}_{\mathrm{DO}}\left(\mathrm{P}_{\mathrm{k}}\right)=$ number of concepts coming out of concept $\mathrm{k}$

$\mathrm{DO}\left(\mathrm{p}_{\mathrm{i}}, \mathrm{p}_{\mathrm{k}}\right)=$ distances: shortest number of paths through which concept $p_{k}$ goes into other concepts in the map

$\mathrm{n}$ = number of concepts in the causal map

Concepts with high out-degree are primarily causal or influential variables that pose contingencies to other concepts in the map. In Appendix IV, concepts A and B have high out-degrees, whereas D has no out-degrees.

For our context, high out-degrees for environmental concepts suggest that firms perceive the environment as a contingency or a given, implying a deterministic causal logic. On the other hand, high 
out-degrees for strategy concepts suggest that strategies can influence the environment and are not merely responses to it. This indicates proactive causal logic.

Capturing in-degree and out-degree based on the number of causal links does not capture the relative importance of the links in the frame. We used the proportion of proactive (number of strategy $\rightarrow$ environment links/total links in the causal map) and deterministic (environment $\rightarrow$ strategy links/total links in the causal map) causal links to identify the relative importance of these links (Carley and Palmquist, 1992; Knoke and Kuklinsky, 1982).

To assess the dimensionality and distinctness of proactive and deterministic thinking, we conducted an exploratory factor analysis of the six measures of proactive and deterministic thinking with varimax rotation. As expected, the factor analyses yielded two distinct factors: proactive (eigenvalue: 3.25, variance 0.45 ) and deterministic (eigenvalue: 2.48, variance 0.36$)$ causal logics. The in-degree of environment (0.87), out-degree of strategy (0.91), and percentage of strategy $\rightarrow$ environment links (0.95) loaded highly on factor-1, which we call proactive causal logic, and had very low loadings on factor2, which we call deterministic causal logic (ranging from 0.29 to 0.68$)$. Similarly, out-degree of environment (0.93), in-degree of strategy (0.89), and percentage of environment $\rightarrow$ strategy links (0.88) had high loadings on deterministic causal logic and low loadings on proactive causal logic (ranging from 0.33 to 0.54). To avoid problems of multicolinearity in our mediated regression analysis (Achen, 1982), we developed composite measure of proactive causal logic by averaging the z-scores of in-degree of environment, out-degree of strategy, and percentage of strategy $\rightarrow$ environment links. Similarly, we created a composite measure of deterministic logic by averaging the z-scores of out-degree of environment, in-degree of strategy, and percentage of environment $\rightarrow$ strategy links. We gathered the proactive and deterministic logic observations for each year from 1970 to 1994 . We lagged the causal logic variables $(t+1)$ by a year behind the industry velocity $(\mathrm{t})$ measures.

\section{Speed of strategic responses}

Previous studies that examine the relationship between environmental beliefs and strategic responses contend that it is important to specify a priori the actions that could be considered as responses to specific environmental factors (Barr, 1998; Barr and Huff, 1997). To identify firm responses to the environmental events identified earlier, we first listed the strategic actions that were identified in a myriad of secondary sources including $10-\mathrm{K}$ reports, U.S. Department of Commerce Industry Outlook reports, announcements in The Wall Street Journal, and published histories of the four industries (Bilstein, 1996; Chapman, 1991; Estrin, 1984; Heppenheimer, 1997) as firm responses to each change in the general and task sectors. There was a high degree of agreement across the document resources in the actions identified as strategic response $(\mathrm{W}=0.85)$. We further validated the responses yielded by the secondary sources through consultations with industry analysts. Two industry analysts familiar with each industry were provided with a list containing the events and the strategic responses derived from secondary sources and asked to select the actions that they considered were responses to each specific event. There was a high degree of convergence between two industry analysts for each industry (semiconductor industry: $W=0.79$, aircraft industry: $\mathrm{W}=0.85$, petrochemical industry: $\mathrm{W}=$ 0.82 , cosmetic industry: $W=0.77)$. Disagreements were resolved through follow-up interviews with each consultant.

Speed of strategic response was measured as the number of days between the occurrence of an event and the initiation of the first strategic response. The fewer the number of days between the occurrence of the environmental event and the initiation of the strategic response, the faster the speed of response. To ascertain the approximate date when each sampled firm initiated the first strategic response action, we content analyzed articles pertaining to each of the responses for the sampled firms in the F\&S Predicast database. This comprehensive source consists of news article titles and abstracts from over 700 newspapers, business magazines, trade association publications, and business newsletters published in the United States (Ferrier, 2001). Most of these articles consistently specified the exact date of the initiation of the response (day, month, year). To allow us to make causal inferences, we measured the attention focus and causal logic variables in the year preceding the year in which we measured speed of strategic response. 


\section{Controls}

We controlled for five industry variables that may affect environmental beliefs as well as strategic responses-industry munificence, industry concentration, capital intensity, R\&D intensity, and advertising intensity. Industry growth or munificence-measured as yearly percentage change in industry gross sales (Dess and Beard, 1984) - reduces the motivation to direct attention to new environmental areas, and engage in aggressive strategic and competitive behavior (Ferrier, 2001). Slow growth often causes more intense competition and lower profitability that motivates paying attention to new environmental areas and engaging in proactive strategic actions (Porter, 1985). High industry concentration (measured as the ratio of sales for the industry's top four companies to total industry sales) limits competitive actions among firms by creating high barriers to entry and yields higher profits to established firms (Porter, 1985). This limits environmental beliefs and strategic responses to actions that leverage existing competencies. High capital intensity (capital expenditures divided by sales) requires firms to invest heavily in long-term assets, which fosters persistence in environmental beliefs and strategic responses (Dess and Beard, 1984). High R\&D (R\&D expenditures divided by sales) and advertising intensity (advertising expenditures divided by sales) encourages innovation and product differentiation that drive proactive search for new ideas and new ways of doing things (Rajagopalan and Datta, 1996). We measured these variables in the years preceding the attention focus and causal logic variables using industry-level data from COMPUSTAT and

\section{U.S. Industry Outlook data published by the U.S. De- partment of Commerce.}

We controlled for two firm-level variables ${ }^{3}-$ sales growth and past performance changes. Previous cognition-related studies have consistently identified the crucial role of both sales growth rates and past performance changes in explaining variations

3 We ran the regressions using three additional firm controlssize (sales and number of employees), age, and diversification. We also reran the regressions using 23 dummy $(0,1)$ variables to control for between-firm differences. However, because none of these variables had any significant effects in any regressions, we did not include them in the final analysis. Excluding these nonsignificant control variables allowed us more degrees of freedom in our analysis. in managerial cognition (Finkelstein and Hambrick, 1996; Weick, 1995; Wiersema and Bantel, 1992). Firm sales growth was defined as the percent change in the total company sales in the three years preceding the attention focus and causal logic variables adjusted for inflation (Guthrie and Olian, 1991; Rajagopalan and Datta, 1996). For example, for causal logic variables in 1970, we measured sales growth from 1967 to 1970.

Drawing on a procedure suggested by Venkatraman and Ramanujam (1987), we created a composite measure of past performance change by averaging yearly changes in the values of three financial measures-return on sales, return on equity, and return on assets. We conducted sensitivity analysis using one, two, and three-year changes in performance variables. The results from two and three year changes in past performance variables did not differ from the results yielded by yearly changes. Therefore we used yearly changes in performance preceding the attention focus and causal logic variables. We collected the performance data from annual COMPUSTAT tapes.

\section{Analyses and Results}

\section{Analyses}

Tests of mediated models in the management literature have been dominated by Baron and Kenny's (1986) causal steps approach, but this approach has been criticized for several shortcomings, including low power to detect effects and high Type I error rates. To overcome these problems, recent studies have proposed bootstrapping procedures for estimating indirect effects of the criterion variables on the outcome variables through the proposed mediators (see MacKinnon et al., 2002; Shrout and Bolger, 2002). Bootstrapping is a nonparametric approach to hypothesis testing that, unlike other methods testing mediation (e.g., Sobel test), imposes no assumptions about the shapes of the distributions of the variables or the sampling distribution of the statistic. In the bootstrapping method, the significance of the indirect paths from the independent variable (industry velocity) to the dependent variables (speed of strategic responses) through the mediators (attention focus and causal logic variables) is explicitly estimated by a product coefficient that is a product of the path coefficient from independent to mediator variables 
and the path coefficient from mediator to the dependent variable.

We used time series cross-sectional (TSCS) regression analysis to estimate the coefficients of the paths from independent to mediator and from mediator to the dependent variables using 25 years of data for the 24 sampled firms. We then used these coefficients in the bootstrapping method to estimate the significance of the indirect paths from industry velocity to speed of strategic response through attention focus and causal logic variables. The use of multiple time periods enhances the reliability of the estimates of the regression parameters (Greene, 1992). The hypothesized relationships between the study variables were modeled as separate equations as follows:

$$
\mathrm{Y}_{\mathrm{it}}=\beta^{\prime} \mathrm{x}_{\mathrm{it}}+\varepsilon_{\mathrm{it}} \quad(\mathrm{i}=1, \ldots, \mathrm{N} ; \mathrm{t}=1, \ldots, \mathrm{T}) .
$$

In the first equation, $X_{i t}$ are the control and independent (industry velocity) variables of industry $i$ in the year $t$ and $Y_{i t}$ are the mediator variables (attention focus and causal logics) of firm i in year $t+1(N=600$ firm-years). In the second set of equations, $X_{i t}$ are the control and independent (industry velocity) variables of industry $i$ in the year $t$ and $Y_{i t}$ are the dependent variables (speed of strategic response to general events: $\mathrm{N}=178$ firm-years, speed of strategic response to task sector changes: $\mathrm{N}=185$ firm-years) of firm $i$ in the year $t+2$ (following the mediator variables). In the final equation, $X_{i t}$ are the control, independent (industry velocity), and mediator variables and $Y_{i t}$ are the dependent variable (speed of strategic response to general events: $\mathrm{N}=178$ firm-years, speed of strategic response to task sector changes: $\mathrm{N}=185$ firm-years) of firm $i$ in the year $t+2$. In the final equation, we first entered controls, followed by mediators (attention focus and causal logics) and finally, the independent variable (industry velocity).

Our data represents TSCS data of 24 firms for 25 years. Efficient and unbiased regression estimation of such TSCS data consisting of long periods for a few firms may depend on correction for some problems. We estimated generalized least squares regression models using the LIMDEP software (Greene, 1992) with the TSCS estimator, which corrects for the following problems:

- groupwise heteroskedasticity, $\mathrm{E}\left[\mathrm{e}^{\wedge} 2(\mathrm{i}, \mathrm{t})\right]=$ sii,

- cross group correlation, $\operatorname{Cov}[\mathrm{e}(\mathrm{i}, \mathrm{t}), \mathrm{e}(\mathrm{j}, \mathrm{t})]=\mathrm{sij}$,

- within group autocorrelation, $\mathrm{e}(\mathrm{i}, \mathrm{t})=\operatorname{rie}(\mathrm{i}, \mathrm{t}-1)$ $+\mathrm{u}(\mathrm{i}, \mathrm{t})$
The TSCS estimator provides consistent estimates in the presence of groupwise heteroskedasticity, and cross-and within-group correlation. The model and the procedures used are those described in Greene (1992) and LIMDEP version 7. We checked for multicolinearity in the models by examining the variance inflation factors for each independent variable. None of the variables were above the recommended values of 10 (Neter, Wasserman, and Kutner, 1985), suggesting that multicolinearity was not a major threat in the regression analysis.

\section{Results}

The descriptives and intercorrelations among study variables are shown in Table 2.

The results of the TSCS mediator regression analysis of the impact of industry velocity (independent variable) on top managers' attention focus and causal logics (mediators) are shown in Table 3. Of the controls, R\&D intensity has a positive relationship with proactive causal logic $(B=0.22, p<0.05)$, a weak negative relationship with deterministic logic $(\mathrm{B}=-0.09, p<0.10)$, and no relationship with attention focus. Past performance change has a positive relationship with proactive causal logic $(B=0.24, p$ $<0.001)$ and a negative relationship with deterministic causal logic $(\mathrm{B}=-0.21, p<0.001)$. The other controls have either a weak relationship $(p<0.10)$ or no relationship with the mediator variables.

Industry velocity has a positive relationship with top managers' attention focus on the task sector (B $=0.51, p<0.001)$ and a negative relationship with attention focus on the general sector $(\mathrm{B}=-0.32, p<$ 0.001). These results support Hypotheses 1 and 2. Industry velocity has a positive relationship with proactive causal logic $(B=0.34, p<0.001)$ and a negative relationship with deterministic causal logic $(\mathrm{B}=$ $-0.39, p<0.001$ ), supporting Hypotheses 3 and 4 .

The results of the bootstrapping mediated regression analyses are shown in Table 4 . The 95 percent confidence intervals are based on bootstrap estimations with 10,000 replications. Recall that speed of response is measured as the number of days between the occurrence of the event and initiation of a response, and therefore has a reverse implicationthe fewer the number of days, the faster the speed of response. The total effects of industry velocity on 
Table 2. Means, standard deviations, and correlation matrix of high and low industries

\begin{tabular}{|c|c|c|c|c|c|c|c|c|c|c|c|}
\hline \multirow[t]{2}{*}{ Variable } & \multicolumn{2}{|c|}{ Descriptives } & \multicolumn{9}{|c|}{ Intercorrelations among study variables } \\
\hline & Mean & SD & 1 & 2 & 3 & 4 & 5 & 6 & 7 & 8 & 9 \\
\hline 1. Sales growth & & & - & & & & & & & & \\
\hline 2. Past performance $\Delta$ & & & $0.25^{*}$ & - & & & & & & & \\
\hline 3. Environment sectors ${ }^{1}$ & - & - & 0.11 & 0.09 & - & & & & & & \\
\hline 4. Industry velocity & - & - & $0.32^{*}$ & $0.27^{*}$ & $0.29^{*}$ & - & & & & & \\
\hline $\begin{array}{l}\text { 5. Attention focus: general } \\
\text { sector }^{3}\end{array}$ & 0.27 & 0.01 & 0.12 & $0.25^{*}$ & $-0.31^{*}$ & $-0.39 * * *$ & - & & & & \\
\hline $\begin{array}{l}\text { 6. Attention focus: task } \\
\text { sector }^{4}\end{array}$ & 0.05 & 0.02 & 0.21 & $0.22^{\dagger}$ & $0.28^{*}$ & $0.45^{* * *}$ & $-0.23^{*}$ & - & & & \\
\hline 7. Proactive causal logics & 0.19 & 0.07 & 0.13 & $0.24^{*}$ & $0.18^{\dagger}$ & $0.41^{* * *}$ & $-0.18^{*}$ & $0.24^{*}$ & - & & \\
\hline 8. Deterministic causal logics & 0.21 & 0.10 & $0.25^{\dagger}$ & $-0.27^{*}$ & $-0.21^{\dagger}$ & $-0.38^{* * *}$ & $0.22 *$ & $-0.21^{*}$ & $-0.32^{* *}$ & - & \\
\hline $\begin{array}{l}\text { 9. Speed of strategic } \\
\text { responses }\end{array}$ & 25.19 & 10.08 & 0.13 & 0.10 & 0.05 & $0.21^{\dagger}$ & -0.10 & $0.18^{\dagger}$ & $0.20^{\dagger}$ & -0.12 & - \\
\hline
\end{tabular}

$\dagger_{p<0.10 ; *}^{*}<0.05 ; * * p<0.01 ; * * * p<0.001$

Environment sectors: general sector $=0$, task sector $=1$

Table 3. TSCS regression results of the effect of industry velocity (independent variable) on attention focus and causal logics (mediator variables)

\begin{tabular}{|c|c|c|c|c|c|c|c|c|}
\hline \multirow[t]{2}{*}{ Independent variable } & \multicolumn{2}{|c|}{$\begin{array}{l}\text { Proactive logic } \\
\qquad(\mathrm{n}=600)\end{array}$} & \multicolumn{2}{|c|}{$\begin{array}{l}\text { Deterministic logic } \\
\qquad(\mathrm{n}=600)\end{array}$} & \multicolumn{2}{|c|}{$\begin{array}{l}\text { Attention focus } \\
\text { on task sector } \\
(n=600)\end{array}$} & \multicolumn{2}{|c|}{$\begin{array}{l}\text { Attention focus on } \\
\text { general sector } \\
(\mathrm{n}=600)\end{array}$} \\
\hline & B & SE B & B & SE B & $\mathrm{B}$ & SE B & $\mathrm{B}$ & SE B \\
\hline \multicolumn{9}{|l|}{ Controls } \\
\hline \multicolumn{9}{|l|}{ Industry controls: } \\
\hline Capital intensity & 0.14 & 0.11 & 0.19 & 0.14 & $0.22^{\dagger}$ & 0.10 & 0.11 & 0.05 \\
\hline R\&D intensity & $0.22^{*}$ & 0.07 & $-0.09^{\dagger}$ & 0.02 & 0.02 & 0.01 & 0.15 & 0.12 \\
\hline Advertising intensity & $0.15^{\dagger}$ & 0.04 & $-0.17^{\dagger}$ & 0.03 & 0.18 & 0.11 & 0.14 & 0.12 \\
\hline Industry concentration & $-0.09^{\dagger}$ & 0.02 & $0.27^{\dagger}$ & 0.11 & 0.12 & 0.07 & 0.24 & 0.19 \\
\hline Industry munificence & $-0.18^{\dagger}$ & 0.07 & 0.05 & 0.03 & 0.07 & 0.09 & 0.07 & 0.11 \\
\hline \multicolumn{9}{|l|}{ Firm controls ${ }^{1}:$} \\
\hline Sales growth & $0.12^{\dagger}$ & 0.04 & $0.25^{\dagger}$ & 0.12 & $0.21^{\dagger}$ & 0.07 & 0.14 & 0.17 \\
\hline Past performance $\Delta$ & $0.24^{*}$ & 0.09 & $-0.21^{*}$ & 0.07 & $0.12^{\dagger}$ & 0.05 & 0.11 & 0.08 \\
\hline$\Delta R^{2}$ & 0.11 & & 0.14 & & 0.09 & & 0.07 & \\
\hline Industry velocity & $0.34^{* * *}$ & 0.05 & $-0.39^{* * *}$ & 0.04 & $0.51^{* * *}$ & 0.07 & $-0.32^{* * *}$ & 0.04 \\
\hline$\Delta R^{2}$ & $0.17^{* * *}$ & & $0.21^{* * *}$ & & $0.24^{* * *}$ & & $0.19^{\star * *}$ & \\
\hline
\end{tabular}

TSCS regression results of the effect of industry velocity (independent variable) on attention focus and causal logics (mediator variables)

${ }^{\dagger} p<0.10 ;{ }^{*} p<0.05 ; * * p<0.01 ; * * * p<0.001$

${ }^{1}$ We created 23 dummy variables to control for firm differences. The results presented in the table are after controlling for the firm dummy variables

speed of response to general sector changes $(\mathrm{B}=-$ $0.24, p<0.001 ; 95 \% \mathrm{CI}=0.029,0.181)$ as well as on speed of response to task sector changes $(B=-0.15$, $p<0.001 ; 95 \% \mathrm{CI}=0.019,0.197)$ are significant. The indirect effects of industry velocity on speed of response to general sector changes through attention focus on general sector ( $B=-0.25, p<0.001$; 95\% $\mathrm{CI}=0.051,0.189)$, attention focus on task sector (B
$=-0.17, p<0.001 ; 95 \% \mathrm{CI}=0.017,0.125)$, proactive $\operatorname{logic}(\mathrm{B}=-0.41, p<0.001 ; 95 \% \mathrm{CI}=0.062,0.171)$, and deterministic logic $(\mathrm{B}=-0.29, p<0.001 ; 95 \% \mathrm{CI}$ $=0.045,0.289)$ are all significant. Similarly, the indirect effects of industry velocity on speed of response to task sector changes through attention focus on general sector $(B=-0.35, p<0.001 ; 95 \% C I=0.064$, $0.358)$, attention focus on task sector $(B=-0.22$, 
Table 4. Results of bootstrapping mediation regression analysis for the relationships between industry velocity, attention focus, causal logics, and speed of strategic response

\begin{tabular}{|c|c|c|c|c|c|c|}
\hline \multirow[t]{2}{*}{$\begin{array}{l}\text { Independent and mediator } \\
\text { variables }\end{array}$} & \multicolumn{3}{|c|}{$\begin{array}{l}\text { Speed of response to general } \\
\text { sector changes }\end{array}$} & \multicolumn{3}{|c|}{$\begin{array}{c}\text { Speed of response to task } \\
\text { sector changes }\end{array}$} \\
\hline & B & S EB & $95 \%$ CI & B & S EB & $95 \%$ CI \\
\hline Industry velocity & $-0.24^{* * *}$ & 0.03 & $0.029,0.181$ & $-0.15^{\star * *}$ & 0.02 & $0.019,0.197$ \\
\hline \multicolumn{7}{|l|}{ Direct effects } \\
\hline Industry velocity & -0.17 & 0.22 & $-0.037,0.156$ & -0.09 & 0.11 & $-0.007,0.054$ \\
\hline \multicolumn{7}{|l|}{ Attention focus } \\
\hline Attention focus on general sector & $-0.25^{* *}$ & 0.03 & $0.051,0.189$ & $-0.35^{* *}$ & 0.07 & $0.064,0.358$ \\
\hline Attention focus on task sector & $-0.17^{* * *}$ & 0.02 & $0.017,0.125$ & $-0.22^{* * *}$ & 0.03 & $0.091,0.314$ \\
\hline Causal logics & & & & & & \\
\hline Proactive logics & $-0.41^{* * *}$ & 0.05 & $0.062,0.171$ & $-0.15^{* * *}$ & 0.02 & $0.051,0.326$ \\
\hline Deterministic logics & $-0.29 * * *$ & 0.03 & $0.045,0.289$ & $-0.25^{\star * *}$ & 0.03 & $0.153,0.294$ \\
\hline
\end{tabular}

${ }^{* *} p<0.01 ; * * * p<0.001$

Table 5. TSCS regression results of attention focus and causal logics (mediators) and speed of response (dependent variable)

\begin{tabular}{|c|c|c|c|}
\hline \multicolumn{2}{|c|}{ Controls } & \multicolumn{2}{|c|}{ Mediators } \\
\hline $\begin{array}{l}\text { Speed of } \\
\text { response to } \\
\text { general events }{ }^{1} \\
(\mathrm{n}=178)\end{array}$ & $\begin{array}{l}\text { Speed of } \\
\text { response to } \\
\text { task events }^{1} \\
(\mathrm{n}=180)\end{array}$ & $\begin{array}{l}\text { Speed of } \\
\text { response to } \\
\text { general events }{ }^{1} \\
\quad(\mathrm{n}=178)\end{array}$ & $\begin{array}{l}\text { Speed of } \\
\text { response to } \\
\text { task events }^{1} \\
(\mathrm{n}=180)\end{array}$ \\
\hline SE B & $\begin{array}{ll}\text { B } & \text { SE B }\end{array}$ & B $\quad$ SE B & B $\quad S E B$ \\
\hline
\end{tabular}

\begin{tabular}{|c|c|c|c|c|c|c|c|c|}
\hline \multicolumn{9}{|l|}{ Controls: } \\
\hline Capital intensity & $0.14 \dagger$ & 0.05 & $0.22 \dagger$ & 0.09 & 0.04 & 0.05 & 0.02 & 0.05 \\
\hline $\mathrm{R} \& \mathrm{D}$ intensity & $-0.09 \dagger$ & 0.04 & $-0.05^{*}$ & 0.01 & -0.17 & 0.14 & -0.11 & 0.15 \\
\hline Advertising intensity & $-0.11 \dagger$ & 0.05 & -0.07 & 0.09 & -0.10 & 0.06 & -0.08 & 0.12 \\
\hline Industry concentration & 0.02 & 0.01 & $0.14 \dagger$ & 0.06 & 0.05 & 0.09 & 0.11 & 0.06 \\
\hline Industry munificence & 0.17 & 0.12 & 0.09 & 0.05 & 0.12 & 0.15 & 0.10 & 0.13 \\
\hline Firm sales growth & $0.22 *$ & 0.04 & $0.18^{*}$ & 0.04 & 0.04 & 0.05 & 0.01 & 0.00 \\
\hline Past performance $\Delta$ & $0.14^{*}$ & 0.02 & $0.24^{*}$ & 0.07 & 0.09 & 0.12 & 0.03 & 0.07 \\
\hline$\Delta R^{2}$ & $0.09 \dagger$ & & $0.12 \dagger$ & & 0.05 & & 0.04 & \\
\hline \multicolumn{9}{|l|}{ Independent variable: } \\
\hline Industry velocity & & & & & -0.07 & 0.04 & -0.10 & 0.07 \\
\hline$\Delta R^{2}$ & & & & & $0.06 \dagger$ & & 0.05 & \\
\hline \multicolumn{9}{|l|}{ Mediating variables: } \\
\hline Proactive logic & & & & & $-0.24^{* * *}$ & 0.03 & $-0.19 * * *$ & 0.02 \\
\hline Deterministic logic & & & & & $0.15^{* * *}$ & 0.02 & $0.05^{* * *}$ & 0.00 \\
\hline Attention focus on general sector & & & & & $-0.03^{* * *}$ & 0.00 & $0.07^{* * *}$ & 0.00 \\
\hline Attention focus on task sector & & & & & $0.17^{* * *}$ & 0.02 & $-0.20 * * *$ & 0.03 \\
\hline$\Delta R^{2}$ & & & & & $0.21^{* * *}$ & & $0.17^{* * *}$ & \\
\hline
\end{tabular}

${ }^{1}$ Speed of response variables have a reverse interpretation - the fewer the number of days between occurrence of general and task events and the initiation of strategic responses, the higher the speed of response and vice versa.

† $p<0.10 ; * p<0.05 ;{ }^{* *} p<0.01 ; * * * p<0.001$

$p<0.001 ; 95 \% \mathrm{CI}=0.091,0.314)$, proactive logic (B $=-0.15, p<0.001 ; 95 \% \mathrm{CI}=0.051,0.326)$, and deterministic logic $(B=-0.29, p<0.001 ; 95 \% C I=0.153$,
0.294) are also significant. Moreover, the direct effects of industry velocity (after entering the mediators) on both speed of response to general sector 
changes ( $\mathrm{B}=0.17$, n.s.; $95 \% \mathrm{CI}=-0.037,0.156)$ and speed of response to task sector changes $(B=0.09$, $p<0.001 ; 95 \% \mathrm{CI}=-0.007,0.054)$ are nonsignificant. This suggests that attention focus and causal logic variables completely mediate the relationships between industry velocity and speed of response to general and task sector changes and support Hypotheses $5,6,7$, and 8 .

To understand the nature of mediation, we estimated the impact of attention focus and causal logic variables on speed of responses. These results are shown in Table 5.

Attention focus on the general sector has a positive relationship (negative coefficient: $\mathrm{B}=-0.03, p<$ 0.001 ) with speed of response to general events, and a negative relationship (positive coefficient: $\mathrm{B}=0.07$, $p<0.001$ ) with speed of response to task events, providing support for Hypotheses 9a and 9b, respectively. In contrast, attention focus on the task sector has a positive coefficient $(B=0.17, p<0.001)$, implying a negative relationship with speed of response to general events and a negative correlation $(\mathrm{B}=-$ $0.20, p<0.001$ ), suggesting a positive relationship with speed of response to task events, which supports Hypotheses 9c and 9d, respectively. Together, the block of attention focus and causal logic variables explains significant incremental variance in speed of response to general $\left(\Delta R^{2}=0.21, p<0.001\right)$ and task $\left(\Delta R^{2}=0.17, p<0.001\right)$ events.

Proactive logic has a negative coefficient, suggesting a positive relationship to speed of response to both general $(\mathrm{B}=-0.24, p<0.001)$ and task $(\mathrm{B}=-$ $0.19, p<0.001)$ events. These results lend support to Hypothesis 10a. In contrast, deterministic logic has a positive correlation, suggesting a negative relationship with speed of response to general $(B=0.15, p$ $<0.001)$ and task $(B=0.05, p<0.001)$ events. Thus, Hypothesis $10 \mathrm{~b}$ is supported.

\section{Discussion}

In this study we sought to unite the economic and cognitive views of strategic action into a more integrated view that takes into account the influence of each. We developed and tested a mediated model in which environment is proposed to influence action through the cognitive frameworks held by top managers. Our results confirm the mediating role of managerial cognition - industry velocity influenced attention focus and causal logics, which in turn, influence speed of strategic response to major changes in the general and task sectors of the environment. Specifically, industry velocity positively influenced top managers' attention focus on task sector and negatively influenced attention focus on general sector. Similarly, industry velocity has a positive relationship with proactive causal logics (strategy $\rightarrow$ environment) and a negative relationship with deterministic causal logics (environment $\rightarrow$ strategy). Further, attention focus and causal logics fully mediated the relationship between velocity and speed of firm response to major changes in the task and general sectors. These findings have important implications for our understanding of the development of top managers' beliefs, the relationship between those beliefs and strategic action, and bring us closer to understanding the complex relationship between industry context, managerial cognition, and strategic action.

\section{Limitations}

Our results highlight intriguing relationships between environment, managerial cognition, and organizational response to environmental events. However, before discussing the implications of these results, it is appropriate to discuss the limitations inherent in the research design that affect their interpretation. First, the use of LTS and concentration on attention focus on external environment and environment-strategy assumptions of firms provide a relatively restricted perspective on managerial cognition. Our focus on a specific type of managerial cognition was motivated by our desire to study the cognition for which there was an existing theoretical basis for expecting a link to environment. Our use of annual reports follows from the longitudinal design of the study, which required similar sources of top management team (TMT) beliefs for 26 firms across four industries over a 25-year period. For such studies, archival data is most feasible and annual reports have been shown to be an acceptable source of managerial beliefs in prior research (Barr et al., 1992; Fiol, 1994). Nevertheless, future study of the links between environment, cognition, and action may wish to focus on other types of beliefs (e.g., action scripts, categorization, attention focus on inter- 
nal organizations, etc.) derived from other types of sources (e.g., internal documents, longitudinal survey techniques).

Interpretation of our results is also limited by the usual concerns about generalizability. We focused on the largest and least diversified firms from four well-established industries. Thus, we can extend our results only to large firms from industries with similar characteristics. Future work that investigates the links between environmental context, managerial cognition, and action that focuses on different industry contexts (e.g., emerging industries, declining industries, service industries), different types of firms (e.g., small or midsized), and different aspects of cognitive representations would provide useful tests of the generalizability of our results.

\section{Implications}

\section{Mediating role of managerial cognition}

In revealing relationships between industry velocity, managerial cognition variables, and speed of strategic action, our study represents an initial step in addressing the disconnect between the industry structure (Bain, 1956; Mason, 1957; Porter, 1985) and managerial cognition views (Barr et al., 1992; Bogner and Barr, 2000; Fiol and O'Connor, 2003; Sutcliffe and Huber, 1998) of strategic actions. This is especially important for the industry velocity context. Empirical studies in this area have revealed differences in the strategic behaviors of firms in high and low velocity environments, but have ignored the role of managerial cognition in driving these behaviors (Brown and Eisenhardt 1997; D'Aveni 1994; Eisenhardt, 1989; Eisenhardt and Martin 2000; Williams, 1994). Our results extend this research by suggesting that industry velocity affects the attention focus and causal logics that top managers develop about their environments, which, in turn, drive the speed of strategic actions. This pattern is consistent with the cognitive explanation of strategic actions, which suggests that incumbent firms enact their environments. However, contrary to prior empirical research on cognition, which only assumes or implies a link between environment and cognition, these results highlight how industry context influences managerial cognition. Our results provide explicit evidence that industry forces significantly and directly influence the cognition process by shaping the attention focus and causal logics that managers use to make sense of and act within the environment. Thus, both industry and cognition variables are critical in developing a comprehensive explanation of strategic action.

The need to take an integrative perspective to the two views of strategic action was raised by Johnson and Hoopes (2003) in their simulation study. However our results differ from theirs in an important way. They found that cognition gains prominence under conditions of costly search and relatively low competitive pressures, whereas the role of cognition is insignificant when competitive pressures increase and costs of search are lower. Our results reveal an influence of cognition on strategic action in both high velocity industries-characterized by strong competitive pressures and low costs associated with experimentation and search (Bogner and Barr, 2000; D'Aveni, 1994) - and low velocity industries, characterized by relatively low competitive pressures in which costs associated with experimentation and proactive search for new strategies are high (D'Aveni, 1994; Eisenhardt and Martin, 2000). The differences in the results between our study and that of Johnson and Hoopes (2003) can be attributed to two factors. First, while Johnson and Hoopes (2003) focus on collective cognition-clusters of shared cognition among groups of firms in an industry, we focus on specific cognitive structures (attention focus and causal logics related to the environment) espoused by top managers from individual firms in different industry contexts. The results of inquiries into shared cognition may not apply to specific facets of cognition such as attention focus and causal logics of top managers in individual firms in an industry. Second, whereas Johnson and Hoopes (2003) used simulation procedures to test propositions on cognition and industry structure, we used a field study approach to examine our model. The differences in the empirical approaches may also have contributed to the deviation in results. In the end, however, both studies point to the importance of both industry structure and cognition in directing firm action.

\section{Industry context and managerial cognition}

Our finding for a direct link between industry velocity and attention focus has implications for the de- 
veloping literature on attention (Ocasio, 1997; Hoffman and Ocasio, 2001). While prior research has proposed that attention is influenced by organizational processes, resources, and performance (Ocasio, 1997; March and Shapira, 1992), the results of the present study suggests that industry significantly influences attention focus. This is consistent with Ocasio's principle of situated attention, which suggests that attention is context specific. However, Ocasio focused primarily on firm-level context, whereas the present study suggests that industry-level context is also important. Additional research to investigate the relative influence of industry- and firm-based contexts, as well as the interaction between the two, would appear to be warranted.

The prominent role of cognition as well as the differences in the type of cognition in high and low velocity industries demonstrated in this study raises the interesting possibility that industry velocity is perpetuated by the beliefs of the TMTs enacting it, which contrasts with most extant literature on industry velocity. This possibility was raised theoretically by Bogner and Barr (2000) and the pattern of results found in the present study is consistent with their arguments. Not only did firms in low velocity industries have a more deterministic perspective than firms in high velocity environments, they took longer to respond to changes in the task sector than the general sector. Firms in high velocity industries, on the other hand, had very proactive beliefs and responded faster to task sector changes, intensifying the speed of competition in high velocity industries. As industry velocity represents the aggregate actions of incumbent firms (Bogner and Barr, 2000; Fines, 1998), differences in strategic actions of incumbent firms driven by differences in attention focus and causal logic may shape the industry velocity.

Finally, we believe this study is the first to explicitly test for links between industry context and managerial cognition. While much of the cognition literature implicitly assumes that cognitive frameworks reflect the unique demands of different industry types, much of the work focuses on levels of cognitive similarity and difference within industries (Barr et al., 1992; Sutcliffe and Huber, 1998; Porac et al., 1995). There is limited empirical evidence of differences in managerial cognitions across industries (Lant et al., 1992; Sutcliffe and Huber, 1998), but em- pirical study focused on identifying systematic differences in managers' subjective representations of environment across different industry contexts has been lacking. The results of this study provide initial confirmation of relationships that are central to managerial cognition research.

\section{Managerial cognition and strategic action}

Our results indicate strong linkages between the attention focus and causal logics developed by top managers and speed of strategic response to environmental events. Where strategic decision makers' attention is focused - on task sectors or on general sectors - affects the speed with which firms respond to events that occur within those sectors; response is faster to those events that occur within the sectors on which the frames are focused. Speed of response is also influenced by beliefs regarding the causal logic linking firm strategy (actions) and environment; deterministic logics (environment $\rightarrow$ strategy) are associated with slower responses than proactive logics (strategy $\rightarrow$ environment).

Taken together, these results contribute to our understanding about the relationship between managerial cognition and strategic response to environmental events. Prior research has linked managerial cognition to the speed and content of organizational response to environmental events (Barr and Huff, 1997; Barr et al., 1992; Dutton and Jackson, 1987; Thomas et al., 1993; Walsh, 1995), but this research has focused primarily on beliefs related to the issue or event itself (e.g., a specific regulatory change, a specific new technology introduced in the industry). Results of these works suggest, for example, that response is linked to the degree to which the event is perceived as an opportunity or threat (Dutton and Jackson, 1987; Thomas et al., 1993) or as having direct negative consequences for firm utility (Barr and Huff, 1997). The results of the present study suggest that patterns of managers' subjective beliefs about the environment in general, and the relationship of these beliefs to strategic action, may influence speed of response independent from any specific beliefs that may be held about the event itself. This raises questions concerning the relative influence of beliefs about industry context (e.g., industry velocity) and beliefs about specific environmental events (e.g., a specific regulatory change, a specific new technol- 
ogy) on the speed of strategic response to environmental events. It also extends prior research in specifying the "boundary conditions" that define the relationship between beliefs of strategic decision makers and speed of response. Future studies may want to build on the results yielded by this study to develop additional boundary conditions for the relationship between beliefs and speed of response.

\section{Industry context and strategic action}

Another interesting question raised by these results concerns the validity of the prescriptive notion that principal or dominant firms respond quickly and decisively to environmental events. Our study suggests that firms within a given context are slower to respond to some environmental events than to others. In high velocity industries, firms responded more quickly to changes occurring in their task sectors, while firms in low velocity industries responded more quickly to events in their general sector. All of our firms were principal in their industry and strong performers, so this result may mean that a faster response is not always the best, or it may mean that the notion of "fast" is relative. Because we did not include smaller or poorer performing firms in this study, we cannot determine which interpretation is more correct. But this does present an interesting opportunity for future research.

\section{Conclusion}

The results of this study suggest that the timing of strategic response to major environmental events varies across industry context and that this variation is tied to beliefs and sense-making processes that vary by industry context. The findings contribute to a more complete understanding of the linkages between environmental context, beliefs, and firm action and bring us a step closer to reconciling economic and cognitive explanations for strategic action.

\section{Acknowledgments}

The authors thank Lisa Lambert and Bill Provaznik for their assistance with the data analysis and Editor Edward Zajac and two anonymous reviewers for Strategic Management Journal for their valuable and constructive comments in the development of the final article.

\section{References}

Achen CH. 1982. Interpreting and Using Regression (Quantitative Applications in the Social Sciences Series). Sage Publications: Thousand Oaks, CA.

Aguilar F. 1967. Scanning the Business Environment. Macmillan Co.: New York.

Anderson J, Gerbing D. 1991. Predicting the performance of measures in a confirmatory factor analysis with a pretest assessment of their substantive validities. Journal of Applied Psychology 76(5): 732-755.

Andrews K. 1987. The Concept of Corporate Strategy. (3rd ed.). Richard Irwin: Homewood, IL.

Axelrod R. 1976. Structure of Decision. Princeton University Press: Princeton, NJ.

Bain JS. 1956. Barriers to New Competition. Harvard University Press: Cambridge, MA.

Baron JN, Bielby WT. 1980. Bringing the firms back in: stratification, segmentation, and organization of work. American Sociological Review 45(5): 737-765.

Baron R, Kenny D. 1986. The moderator-mediator variable distinction in social psychological research: conceptual, strategic and statistical considerations. Journal of Personality and Social Psychology 51(6): 1173-1182.

Barr PS. 1998. Adapting to unfamiliar environmental events: a look at the evolution of interpretation and its role in strategic change. Organization Science 9(6): 644-669.

Barr PS, Huff AS. 1997. Seeing isn't believing: understanding diversity in the timing of strategic response. Journal of Management Studies 34(3): 337-370.

Barr PS, Stimpert JL, Huff AS. 1992. Cognitive change, strategic action and organizational renewal. Strategic Management Journal Summer Special Issue 13: 15-36.

Baum JR, Wally S. 2003. Strategic decision speed and firm performance. Strategic Management Journal 24(11): 1107-1129.

Bergh DD, Lawless MW. 1998. Portfolio restructuring and limits to hierarchical governance: the effects of environmental uncertainty and diversification strategy. Organization Science 9(1): 87-102.

Bettman JR, Weitz A. 1983. Attributions in the board room: causal reasoning in corporate annual reports. Administrative Science Quarterly 28(2): 165-183.

Bilstein A. 1996. The American Aerospace Industry: From Workshop to Global Enterprise. Twayne Publishers: New York.

Bogner W, Barr P. 2000. Making sense in hypercompetitive environments: a cognitive explanation for the persistence of high velocity competition. Organization Science 11(2): 212-226. 
Borgatti S. 2005. Centrality and network flow. Social Networks 27(1): 55-71.

Bougon MK., Weick KE, Binkhorst D. 1977. Cognition in organizations: an analysis of the Utrecht JazZ Orchestra. Administrative Science Quarterly 22(4): 609-639.

Bourgeois LJ. 1980. Strategy and environment: a conceptual integration. Academy of Management Review 5(1): 25-39.

Bourgeois LJ, Eisenhardt KM. 1988. Strategic decision processes in high velocity environments: four cases in the microcomputer industry. Management Science 34(7): 816-835.

Bowman EH. 1978. Strategy, annual reports, and alchemy. California Management Review 3(20): 64-71.

Brown SL, Eisenhardt KM. 1997. The art of continuous change: linking complexity theory and time-paced evolution in relentlessly shifting organizations. Administrative Science Quarterly 42(1): 1-34.

Cameron K, Sutton R, Whetten DA (eds). 1988. Readings in Organizational Decline: Frameworks, Research, and Prescriptions. Ballinger: Boston, MA.

Carley C, Palmquist M. 1992. Extracting, representing and analyzing mental models. Social Forces 70(3): 601-636.

Caves RE, Fortunato M, Ghemawat P. 1984. The decline of dominant firms, 1905-1929. Quarterly Journal of Economics 99(3): 523-546.

Chakravarthy B. 1982. Adaptation: a promising metaphor for strategic management. Academy of Management Review 7(1): 35-44.

Chapman K. 1991. The International Petrochemical Industry: Evolution and Location. Basil Blackwell: Oxford. UK.

Child J. 1972. Organizational structure, environment and performance: the role of strategic choice. Sociology 6(1): 1-22.

Cho TS, Hambrick D. 2006. Attention as the mediator between the top management team characteristics and strategic change: the case of airline deregulation. Organization Science 17(4): 453-469.

Clapham SE, Schwenk CR. 1991. Self-serving attributions, managerial cognition, and company performance. Strategic Management Journal 12(3): 219-229.

Cottrell T, Nault BR. 2004. Product variety and firm survival in the microcomputer software industry. Strategic Management Journal 25(10): 1005-1026.

Daft RL, Sormunen J, Parks D. 1988. Chief executive scanning, environmental characteristics, and company performance: an empirical study. Strategic Management Journal 9(2): 123-139.
Daft RL, Weick KE. 1984. Toward a model of organizations as interpretive systems. Academy of Management Review 9(2): 284-295.

Dalton DR, Kesner IF. 1983. Inside/outside succession and organizational size: the pragmatics of executive replacement. Academy of Management Journal 26(4): 736-742.

D'Aveni R. 1994. Hypercompetition: Managing the Dynamics of Strategic Maneuvering. Free Press: New York.

Davis GF, Diekmann K, Tinsley C. 1994. The decline and fall of the conglomerate firm in the 1980s: the deinstitutionalization of an organization form. American Sociological Review 59(4): 547-570.

Dearborn DC, Simon HA. 1958. Selective perception: a note on the departmental identifications of executives. Sociometry 21: 140-144.

Dess GG, Beard DW. 1984. Dimensions of organizational task environments. Administrative Science Quarterly 29(1): 52-73.

Duncan RB. 1972. Characteristics of perceived environment and perceived environmental uncertainty. Administrative Science Quarterly 17(3): 313-327.

Dutton JE, Duncan RB. 1987. The creation of momentum for change through the process of strategic issue diagnosis. Strategic Management Journal 8(3): 279-295.

Dutton JE, Fahey L, Narayanan VK. 1983. Toward understanding strategic issue diagnosis. Strategic Management Journal 4(4): 307-323.

Dutton JE, Jackson SE. 1987. Categorizing strategic issues: links to organizational action. Academy of Management Review 12(1): 76-90.

Eden C, Ackermann F, Cropper S. 1992. The analysis of cause maps. Journal of Management Studies 29(3): 309-324.

Eisenhardt KM. 1989. Making fast strategic decisions in high velocity environments. Academy of Management Journal 32(3): 543-576.

Eisenhardt KM, Martin JA. 2000. Dynamic capabilities: what are they? Strategic Management Journal OctoberNovember Special Issue 21: 1105-1121.

Erdener CB, Dunn CP. 1990. Content analysis. In Mapping Strategic Thought, Huff AS. (ed). John Wiley \& Sons Ltd.: London; 291-300.

Estrin NE. 1984. The Cosmetic Industry: Scientific and Regulatory Foundations (Cosmetic Science and Technology Series 2). Marcel Dekker Inc.: Basel, NY.

Eye A. 1990. Statistical Methods for Longitudinal Research (Vol. 2). Academic Press: Boston, MA.

Fahey L, Narayanan VK. 1989. Linking changes in revealed causal maps and environmental change: an 
empirical study. Journal of Management Studies 26(4): 361-378.

Ferrier W. 2001. Navigating the competitive landscape: the drivers and consequences of competitive aggressiveness. Academy of Management Journal 44(4): 858-877.

Ferrier W, Smith K, Grimm C. 1999. The role of competitive action in market share erosion and industry dethronement: a study of industry leaders and challenger. Academy of Management Journal 42(4): 372-388.

Fines C. 1998. Clockspeed: Winning Industry Control in the Age of Temporary Advantage. Perseus Books: Reading, MA.

Finkelstein S, Hambrick D. 1996. Top Executives and Their Effects on Organizations. West Publishing Company: St. Paul, MN.

Fiol CM. 1989. A semiotic analysis of corporate language: organizational boundaries and joint venturing. Administrative Science Quarterly 34(2): 277-303.

Fiol CM. 1994. Consensus, diversity, and learning in organizations. Organization Science 5(3): 403-420.

Fiol CM. 1995. Corporate communications: comparing executives' private and public statements. Academy of Management Journal 38(2): 522-536.

Fiol CM, O'Connor EJ. 2003. Waking up! Mindfulness in the face of bandwagons. Academy of Management Review 28(1): 54-70.

Fiske ST, Taylor SE. 1991. Social Cognition. McGraw-Hill: New York.

Ford J, Hegarty H. 1983. Decision makers' beliefs about the causes and effects of structure: an exploratory study. Academy of Management Journal 27(2): 271-291.

Freeman LC. 1978/1979. Centrality in social networks: conceptual clarification. Social Networks 1(3): 215-239.

Garg VK, Walters BA, Priem RL. 2003. Chief executive scanning emphases, environmental dynamism, and manufacturing firm performance. Strategic Management Journal 24(8): 725-744.

Ghemawat P. 1991. Commitment: The Dynamic of Strategy. Free Press: New York.

Ghemawat P, Rivkin J. 1999. Creating Competitive Advantage. Harvard Business School Press: Boston, MA.

Ginsberg A. 1988. Measuring and modelling changes in strategy: theoretical foundations and empirical directions. Strategic Management Journal 9(6): 559-575.

Glueck WF, Willis R. 1972. Documentary sources and strategic management research. Academy of Management Review 4(1): 95-102.

Golden BR. 1992. The past is the past-or is it? The use of retrospective accounts as indicators of past strategy. Academy of Management Journal 35(4): 848-860.

Goldstein A, Aspray W. 1997. Facets: New Perspectives on the History of Semiconductors. IEEE Center for the History of Electrical Engineering: New Brunswick, NJ.

Greene WH. 1992. LIMDEP User's Manual and Reference Guide. Econometric Software, Inc.: Plainview, NY.

Greenwood R, Suddaby R, Hinnings C. 2002. Theorizing change: the role of professional associations in the transformation of institutionalized fields. Academy of Management Journal 45(1): 58-90.

Gupta AK. 1988. Technological intensity and choice of diversification strategy. In Proceedings '88: Managing the High Technology Firm. Gomez-Mejia LR, Lawless MW. (eds). The University of Colorado: Boulder, CO.; 78-84.

Guthrie J, Olian J. 1991. Does context affect staffing decisions? The case of general managers. Personnel Psychology 44(2): 263-292.

Hambrick DC, D'Aveni RA. 1988. Large corporate failures as downward spirals. Administrative Science Quarterly 33(1): 1-23.

Hambrick DC, Lei D. 1985. Toward an empirical prioritization of contingency variables for business strategy. Academy of Management Journal 28(4): 763-788.

Hambrick DC, Mason PA. 1984. Upper echelons: the organization as a reflection on its top managers. Academy of Management Review 9(2): 193-206.

Haveman HA. 1992. Between a rock and a hard place: organizational change and performance under conditions of fundamental environmental transformation. Administrative Science Quarterly 37(1): 48-75.

Heppenheimer TA. 1997. The History of Commercial Aviation. John Wiley \& Sons: New York.

Hill CWL, Hansen GS. 1991. A longitudinal study of the cause and consequences of changes in diversification in the U.S. pharmaceutical industry: 1977-1986. Strategic Management Journal 12(3): 187-199.

Hitt M, Ireland D, Hoskisson R. 2004. Strategic Management: Competitiveness and Globalization. West Publishing Company: Minneapolis/St. Paul, MN.

Hofer CW, Schendel D. 1978. Strategy Formulation: Analytical Concepts. West Publishing Company: Minneapolis/St. Paul, MN.

Hoffman AJ, Ocasio W. 2001. Not all events are attended equally: toward a middle-range theory of industry attention to external events. Organization Science 12(4): 414-425.

Huff AS. 1982. Industry influences on strategy reformulation. Strategic Management Journal 3(2): 119-131. 
Huff AS. 1990. Mapping Strategic Thought. John Wiley \& Sons: Chichester, UK.

Huff AS, Schwenk C. 1990. Bias and sensemaking in good times and bad. In Mapping Strategic Thought, Huff AS. (ed). John Wiley \& Sons: Chichester, UK.: 81-108.

Johnson DR, Hoopes DG. 2003. Managerial cognition, sunk costs, and the evolution of industry structure. Strategic Management Journal October Special Issue 24: 1057-1068.

Judge W, Miller A. 1991. Antecedents and outcomes of decision speed in different environmental contexts. Academy of Management Journal 34(2): 449-463.

Jurkovich R. 1974. A core typology of organizational environments. Administrative Science Quarterly 19(3): 380-394.

Katila R, Ahuja G. 2002. Something old, something new: a longitudinal study of search behavior and new product introduction. Academy of Management Journal 45(6): 1183-1195.

Keats BW, Hitt MA. 1988. A causal model of linkages among environmental dimensions, macro organizational characteristics and performance. Academy of Management Journal 31(3): 570-598.

Knoke D, Kuklinsky JH. 1982. Network Analysis (Series Quantitative Applications in the Social Sciences). Sage Publications: London, UK.

Lant TK, Milliken FJ, Batra B. 1992. The role of managerial learning and interpretation in strategic persistence and reorientation: an empirical exploration. Strategic Management Journal 13(8): 585-608.

Lyles MA, Schwenk CR. 1992. Top management, strategy and organizational knowledge structures. Journal of Management Studies 29(2): 155-174.

MacKinnon DP, Lockwood CM, Hoffman JM, West SG, Sheets V. 2002. A comparison of methods to test the significance of the mediated effect. Psychological Methods 7(1): 83-104.

March JG, Shapira Z. 1992. Variable risk preferences and the focus of attention. Psychological Review 99(1): 172-183.

March JG, Simon HA. 1958. Organizations. John Wiley \& Sons: New York.

Martin X, Mitchell W. 1998. The influence of local search and performance heuristics on new design introduction in a new product market. Research Policy 26(7-8): 753-771.

Mason ES. 1957. Economic Concentration and the Monopoly Problem. Harvard University Press: Cambridge, MA.

Mendelson H, Pillai RR. 1999. Industry clockspeed: mea- surement and operational implications. Manufacturing and Service Operations Management 1(1): 1-20.

Miles RE, Snow CC. 1972. Organizational Strategy, Structure and Process. McGraw-Hill: New York.

Miller D, Lant TK, Milliken FJ, Korn HJ. 1996. The evolution of strategic simplicity: exploring two models of organizational adaptation. Journal of Management 22(6): 863-887.

Mintzberg H. 1972. The manager's job: folklore and fact. In Managing People and Organizations, Gabarro JJ. (ed). McGraw-Hill: Boston, MA.; 13-32.

Nadkarni S, Narayanan VK. 2005. Validity of the structural properties of text-based causal maps: an empirical analysis. Organizational Research Methods 8(1): 9-40.

Nieminen J. 1974. On centrality in a graph. Scandinavian Journal of Psychology 15: 322-336.

Nerkar A, Roberts PW. 2004. Technological and product-market experience and the success of new product introductions in the pharmaceutical industry. Strategic Management Journal August-September Special Issue 25: 779-799.

Neter J, Wasserman W, Kutner M. 1985. Applied Linear Statistical Models. Irwin: Homewood, IL.

Ocasio W. 1997. Towards an attention-based view of the firm. Strategic Management Journal Summer Special Issue 18: 187-206.

Osborne JD, Stubbart CI, Ramaprasad A. 2001. Strategic groups and competitive enactment: a study of dynamic relationships between mental models and performance. Strategic Management Journal 22(5): 435-454.

Porac J, Thomas H, Wilson F, Paton D, Kanfer A. 1995. Rivalry and the industry model of Scottish knitwear producers. Administrative Science Quarterly 40(2): 203-227.

Porter M. 1985. Competitive Advantage. Free Press: New York.

Prahalad CK, Bettis RA. 1986. The dominant logic: a new linkage between diversity and performance. Strategic Management Journal 7(6): 485-501.

Priem RL. 1994. Executive judgment, organizational congruence, and firm performance. Organization Science 5(3): 421-437.

Quinn J. 1980. Strategies for Change: Logical Incrementalism. Irwin: Homewood, IL.

Rajagopalan N, Datta DK. 1996. CEO characteristics: does industry matter? Academy of Management Journal 39(1): 197-215.

Reger RK, Huff AS. 1993. Strategic groups: a cogni- 
tive perspective. Strategic Management Journal 14(2): 103-124.

Reger RK, Palmer TB. 1996. Managerial categorization of competitors: using old maps to navigate new environments. Organization Science 7(1): 22-39.

Rumelt RP. 1974. Strategy, Structure, and Economic Performance. Harvard Business School Press: Boston, MA.

Salancik GR, Meindl JR. 1984. Corporate attributions as strategic illusions of management control. Administrative Science Quarterly 29(2): 238-254.

Scott J. 2000. Social Network Analysis: A Handbook (2nd edn). Sage Publications: London, UK.

Shrout PE, Bolger N. 2002. Mediation in experimental and nonexperimental studies: new procedures and recommendations. Psychological Methods 7(4): 422-445.

Simon HA. 1991. Organizations and markets. Journal of Economic Perspectives 5(2): 25-44.

Smith KG, Grimm CM. 1987. Environmental variation, strategic change and firm performance: a study of railroad deregulation. Strategic Management Journal 8(4): 363-376.

Snyder NH, Glueck WH. 1982. Can environmental volatility be objectively measured? Academy of Management Journal 25(1): 185-192.

Starbuck W, Milliken F. 1988. Executive perceptual filters: what they notice and how they make sense. In The Executive Effect: Concepts and Methods for Studying Top Managers (Strategic Management Policy and Planning, Vol. 2), Hambrick D (ed). JAI Press: Greenwich, CT.; 35-65.

Staw B, McKechnie P, Puffer S. 1983. The justification of organizational performance. Administrative Science Quarterly 28(4): 582-600.

Stubbart CI. 1989. Managerial cognition: a missing link in strategic management research. Journal of Management Studies 26(4): 325-347.

Sutcliffe KM, Huber GP. 1998. Firm and industry as determinants of executive perceptions of the environment. Strategic Management Journal 19(8): 79-807.

Terreberry S. 1968. The evolution of organizational environments. Administrative Science Quarterly 12(4): 590-613.

Thomas JB, Clark SM, Gioia DA. 1993. Strategic sensemaking and organizational performance: linkages among scanning, interpretation, action and outcomes. Academy of Management Journal 36(2): 239-270.

Tung R. 1979. Dimensions of organizational environments: an exploratory study of their impact on organization structure. Academy of Management Journal 22(4): 672-693.

Tushman ML, Anderson PC. 1986. Technological discontinuities and organizational environments. Administrative Science Quarterly 31(3): 439-465.

Tushman ML, Romanelli E. 1994. Organizational evolution: a metamorphosis model of convergence and reorientation. Research in Organizational Behavior 7: 171-222.

U.S. Department of Commerce, International Trade Administration. 1993. U.S Industrial Outlook 1993. U.S. Government Printing Office: Washington, DC.

U.S. Department of Commerce, International Trade Administration. 1994. U.S Industrial Outlook 1994. U.S. Government Printing Office: Washington, DC.

U.S. Department of Commerce, International Trade Administration. 1997. U.S. Industry and Trade Outlook 1997. McGraw-Hill Companies: New York.

Venkatraman N, Ramanujam V. 1987. Measurement of business economic performance: an examination of method convergence. Journal of Management 13(1): 109-122.

Walsh JP. 1995. Managerial and organizational cognition: notes from a trip down memory lane. Organization Science 6(3): 280-321.

Weick K. 1995. Sensemaking in Organizations. Sage: London, UK.

Wiersema MF, Bantel KA. 1992. Top management team demography and corporate strategic change. Academy of Management Journal 35(1): 91-121.

Williams J. 1994. Strategy and the search for rents: the evolution of diversity among firms. In Fundamental Issues in Strategy, A Research Agenda, Rumelt RP, Schendel D, Teece DJ (eds). Harvard Business School Press: Boston, MA.; 229-246.

Williamson OE. 1963. Managerial discretion and business behavior. American Economic Review 53(5): 1032-1057.

Wooldridge B, Floyd SW. 1989. Strategic process effects on consensus. Strategic Management Journal 10(3): 295-302. 
Appendix I. Demographic Summary of Sampled Firms

\begin{tabular}{lccc}
\hline Company & $\begin{array}{c}\text { Mean sales } \begin{array}{c}\text { (1970-1994) } \\
\text { in millions }\end{array} \\
\text { Aircraft industry }\end{array}$ & $\begin{array}{c}\text { Market share } \\
(\%)\end{array}$ & $\begin{array}{c}\text { Mean number of } \\
\text { employees (1970-1994) }\end{array}$ \\
1. Boeing & 12602.88 & 23.94 & 104,700 \\
2. McDonnell Douglas & 8966.74 & 17.87 & 86,919 \\
3. Lockheed Martin & 7788.36 & 16.06 & 77,588 \\
4. Raytheon & 5654.73 & 11.50 & 65,521 \\
5. General Dynamics & 5106.50 & 11.47 & 76,099 \\
6. Northrop Corporation & 3337.85 & 6.30 & 33,094 \\
7. Grumann Aerospace Corporation & 2249.748 & 5.31 & 27,717 \\
Petrochemical industry & & & \\
1. Dow Chemicals & 21120.74 & 22.85 & 54,108 \\
2. Dupont & 27648.16 & 26.89 & 133,963 \\
3. Sherwin-Williams & 2877.85 & 6.12 & 18,783 \\
4. PPG Industries & 4826.76 & 9.15 & 36,034 \\
5. Ashland & 6629.63 & 8.89 & 30,883 \\
Semiconductor industry & & & \\
1. Intel & 2775.47 & 21.35 & 33,748 \\
2. Advanced Micro Devices & 783.24 & 8.48 & 13,067 \\
3. National Semiconductors & 1157.1 & 8.91 & 35,701 \\
4. Texas Instruments & 3077.14 & 23.67 & 89,874 \\
5. LSI Logic & 489.45 & 4.99 & 9,567 \\
6. Vishay Intertechnology & 346.04 & 3.69 & 8,926 \\
7. Analog Devices & 354.18 & 3.89 & 8,521 \\
Cosmetic industry & & & 3,918 \\
1. Revlon & 2909.32 & 23.84 & 3,271 \\
2. Avon & 2547.90 & 17.59 & 36,533 \\
3. Colgate-Palmolive & 4565.45 & 31.89 & 30,731 \\
4. Helene Curtis & 851.79 & 5.72 & 38,100 \\
5. Carter Wallace & 564.54 & & \\
\hline
\end{tabular}


Appendix II. An Illustration of the Five-Step Procedure of Constructing Causal Maps

$\underline{\text { STEP I }}$

Identification of causal statements

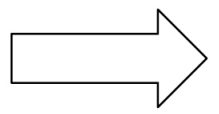

$\underline{\text { STEP } 2}$

Constructing raw causal maps

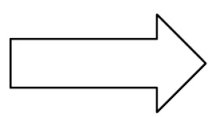

$\underline{\text { STEP } 3}$ Organizing raw concepts into broad conceptual categories

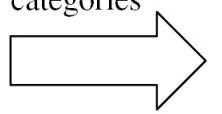

Example of a causal statement:

'In order to meet evolving needs of our major customers, we must achieve a rapid migration to our next-generation technology'

Raw causal concept Causal connector Raw effect concept

Evolving consumer In order to Adapt to new demand technology

(To meet evolving demands of our major customers)

(we must achieve a rapid migration to our nextgeneration technology) $\underline{\text { STEP } 4}$

Recast raw concepts into conceptual categories to construct coded causal map

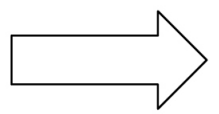

\section{$\underline{\text { Coded causal map }}$}

Customer/market characteristics

Competitive strategy 
Appendix III. Theoretical Categories Used to Code Raw Environmental and Strategy Concepts in the Causal Maps

\section{General Sector}

1. Macroeconomic environment:

- Change in government administration

- Change in government policies

- Recession in the United States

- Global recession

- Asian financial crises

2. Political environment:

- Persian-Gulf War

- International U.S. relations

- Political conflicts and hostilities

- Economic conditions

- Asian financial crisis

3. Regulatory environment:

- Changes in domestic regulations

- Changes in regulations in other countries

- Changes in World Trade Organization (WTO) regulations

\section{Task Sector}

1. Customer/market environment:

- Diversity of market segments

- Growth of specific markets

- Evolving customer demand

- Diverse customer needs within a segment

- Market fragmentation

- Market convergence

- Emerging market segments

- Shifts in buyer demographics

- Emerging buyer preferences

2. Competitive environment:

- Industry concentration

- Importance of brand name

- Ease of exit

- Profit margins

- Resource requirements

- Cost disadvantages independent of size

- Access to distribution channels

- Imitators

- Increased competition from alternative producers

- Cooperative alliances of competitors

- Market saturation

- Global competition

- Decline in barriers to entry

- New entrants

- Closeness of substitute products

- Prices of substitute products

- Performance of substitute products
5. Technological environment:

- Access to technology and know-how

- Intellectual property rights

- Product innovation

- Technological change

- Market innovation

- Diffusion of technological know-how

6. Suppliers

- Scarcity of raw materials

- Supplier dominance

- Diversity of suppliers

\section{Strategy Content}

1. Corporate strategy

- Acquisition

- Merger

- Cooperative ties with international firms

- Cooperative agreement with domestic firms

- Joint venture

- Cooperative ties with suppliers

- Turnaround strategy

- Consolidation

- Divestiture/sale of business units

- Business focus versus diversification

- Allocation of resources

- Expansion of product lines

- Nontraditional expansion opportunities

2. Competitive strategy

- Product customization

- On time product deliveries

- Enhanced customer service

- New product introduction

- Product development

- R\&D expenditures

- Adapt to new technologies

- Fast introduction of products

- Product technology focus

- Dealer incentives

- Alliances with dealers

- Advertising

- New channels of distribution

- Brand promotion

- Expansion of marketing programs

- Minimum tooling

- Lower inventory levels

- Product delivery on time

- Lower production cost

- Powerful suppliers

- Economies of scale

- Increase productivity 
- Lower waste

- Production rates

- Expansion/reduction of manufacturing capacity

- Computerized manufacturing

- New equipment and facilities

- Capital expenditures

- Increased outsourcing

- Reallocation of existing capacity

\section{Strategy Process}

3. Organizational structure

- Simplify organizational structures

- Decentralize

- Develop flexible structures

- Delete layers of management
4. People

- Stock incentive programs

- Down-size

- Select, promote, and train employees

- Labor negotiations

5. Business processes

- Simplify business processes

- Promote understanding of long-term objectives

- Improve resource use

6. Strategic controls

- Develop communication systems

- Strengthen control and procedural systems

- Improve reporting systems

- Budget

Appendix IV. Illustration of Centrality, In-Degree and Out-Degree Measures in a Causal Map

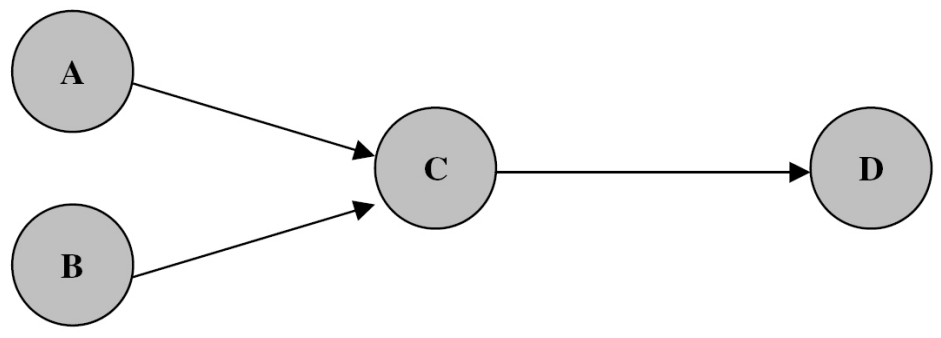

\section{CENTRALITY}

Degree centrality: $\mathrm{A}=0.33, \mathrm{~B}=0.33, \mathrm{C}=1.0, \mathrm{D}=0.33$

Closeness centrality: $\mathrm{A}=0.60, \mathrm{~B}=0.60, \mathrm{C}=10.0, \mathrm{D}=0.60$

\section{IN-DEGREE}

$\mathrm{A}=0.00, \mathrm{~B}=0.00, \mathrm{C}=0.67, \mathrm{D}=0.67$

\section{OUT-DEGREE}

$\mathrm{A}=0.50, \mathrm{~B}=0.50, \mathrm{C}=0.33, \mathrm{D}=0.00$ 